\title{
Fracture of aluminium reinforced with densely packed ceramic particles: influence of matrix hardening
}

\author{
Ali Miserez ${ }^{1}$, Andreas Mortensen * \\ Laboratory for Mechanical Metallurgy, Institute of Materials, Swiss Federal Institute of Technology in Lausanne (EPFL), Room MX-D 140, \\ Bâtiment des Matériaux, 1006 Lausanne CH1015, Switzerland
}

Received 30 June 2004; received in revised form 21 July 2004; accepted 23 July 2004

Available online 3 September 2004

\begin{abstract}
$\mathrm{Al}-\mathrm{Cu}$ matrix composites with a high volume fraction of alumina particles (41-62\%) prepared by gas-pressure infiltration are characterized in tension and chevron-notch fracture testing before and after heat-treatment. Their mechanical behaviour is shown to depend markedly on the matrix structure and flow stress, and also on the nature and size of the reinforcement particles. Al-Cu matrix composites free of coarse $\mathrm{Al}_{2} \mathrm{Cu}$ matrix intermetallics and reinforced with $60 \mathrm{vol} \%$ high-strength polygonal alumina particles exhibit strength/toughness combinations that are in the same range as unreinforced high-strength aluminium alloys: the strength of the composites can be increased without decreasing their toughness. The results are interpreted on the basis of current cohesive zone models for crack propagation by microcavitation in elastic-plastic materials.
\end{abstract}

(C) 2004 Acta Materialia Inc. Published by Elsevier Ltd. All rights reserved.

Keywords: Metal matrix composites; Liquid infiltration; Fracture toughness; Interfacial phases; Cohesive zone models

\section{Introduction}

In particulate ceramic reinforced metals produced by infiltration, the ceramic particles are packed to volume fractions of around $50 \%$ or more. This is significantly above ceramic loadings in corresponding composites produced by stir-casting or powder metallurgy, which have been the main focus of research on particle reinforced metals for structural applications: these generally contain at most $30 \%$ ceramic [1-5]. Infiltrated particle reinforced metals are therefore qualitatively different from their lower-volume fraction ceramic counterparts: with fully packed particles, there is ceramic particle con\footnotetext{
4664.

* Corresponding author. Tel.: +41 21693 2912; fax: +41 21693

E-mail addresses: ali@engineering.ucsb.edu (A. Miserez), andreas.mortensen@epfl.ch (A. Mortensen).

${ }^{1}$ Present address: Materials Department, College of Engineering, University of California, Santa Barbara (UCSB), USA.
}

tact throughout the composite and the ductile matrix cannot deform freely around each ceramic particle. Few data exist on the mechanical properties of such composites: with their high ceramic content, they are seldom considered to be materials having promise in structural applications. As a consequence, trends and limits in their properties are little-known or unclear. Their fracture toughness, like their tensile strength and ductility, has in the few investigations to date been found to be highly variable and strongly system-dependent, varying between 3 and roughly $20 \mathrm{MPa} \sqrt{ } \mathrm{m}$ [6-9]. One general trend that is observed is that, as the particle diameter increases, the fracture toughness increases [7,10-14]. In one study of alumina-reinforced composites produced by capillarity-driven infiltration, it was also found that toughness, when expressed as a stressintensity factor, is relatively independent of particle volume fraction [9].

The present investigation is part of a systematic exploration of microstructure-property relations in model 
composites of aluminium-based matrices reinforced with fully packed monosized alumina particles. It was reported in a previous paper on the fracture of pure Al reinforced with densely packed alumina particles [15] that such composites can actually be made quite tough, with fracture toughness values as high as $40 \mathrm{MPa} \sqrt{ } \mathrm{m}$ despite the high ceramic loadings. By varying systematically the particle size as well as its type, a direct and linear correlation was found between the local work of fracture spent in creating the fracture surface, $2 \gamma_{\mathrm{pz}}$ and the macroscopic fracture energy at the initiation of ductile tearing, $J_{\mathrm{c}}$. This finding provides guidelines for microstructural design of these composites: a corollary is notably that the particulate reinforcement defect population and its mean size are two parameters that both exert a direct, nearproportional, influence on the toughness of such ductile-brittle two-phase materials.

The role of the matrix flow stress on fracture of the composites was not assessed in this previous study, since all composites were made with a matrix of pure aluminium. We thus explore here the influence of increased matrix flow stress. This will obviously increase the yield strength of the composites, but is also likely to decrease their toughness: in structural materials having optimized microstructures, increased strength generally comes at the expense of decreased toughness (e.g., in optimally heat-treated aluminium alloys [16]).

Relevant background may be sought in studies of the influence exerted by the matrix flow stress on the toughness of more conventional structural ceramic particle reinforced metals, containing $30 \%$ or less ceramic. The literature on the subject has been comprehensively reviewed by several authors [6,17-19]; it emerges that the influence exerted by the matrix flow stress on the toughness of ceramic particle reinforced metals of lower ceramic content is not simple, mainly because variegated microstructural factors often hinder interpretation. One complication is that chemical reactions can occur between matrix alloying elements (such as magnesium typically present in high-strength aluminium alloys) and the reinforcement, especially when liquid metal processing is used to produce the composite [20]. Interfacial reactions generally degrade the mechanical performance of the composites (e.g., [21,22]) and complicate data interpretation since a new phase is introduced. Another factor that can complicate the influence of the matrix strength on toughness is the interaction between matrix precipitate formation and the reinforcements, leading in particular to a lack of toughness recovery upon overaging caused by the presence of brittle matrix precipitates along the particle/matrix interface [6,23-27]. Thus, if the matrix microstructure is not optimized, for example to avoid matrix/ceramic interface weakening by interfacial reaction or interfacial precipitate formation, degraded toughness results, masking in turn the optimum com- promise that can be reached between strength and toughness in these materials.

In order to unambiguously assess the influence of the matrix flow stress on the toughness of high volume fraction PRMMCs, we have therefore selected a simple binary matrix that remains chemically inert with alumina and that can be made to feature a homogeneous microstructure free of embrittling compound formation. The well-known binary Al-Cu matrix system was chosen because: (i) a simple microstructure can be obtained, consisting of a single solid-solution phase of $\mathrm{Cu}$ in $\mathrm{Al}$ that is retained by quenching, and (ii) both liquid $\mathrm{Al}$ and $\mathrm{Cu}$ are inert in contact with alumina. Two compositions, namely $\mathrm{Al}-2 \mathrm{wt} \% \mathrm{Cu}$ and $\mathrm{Al}-4.5 \mathrm{wt} \% \mathrm{Cu}$, were selected; these are within the solubility limit of $\mathrm{Cu}$ in $\mathrm{Al}$ near the eutectic [28]. The fracture characteristics of these Al-Cu matrix composites can thus be directly compared with those of pure $\mathrm{Al}$ matrix composites of [15]: they all exhibit a similar microstructure made of stiff ceramic particles embedded within a single-phase, ductile matrix.

\section{Experimental procedures}

\subsection{Materials processing and designation}

The composites were produced by gas-pressure infiltration, as described in [29-31]. Al-2wt $\% \mathrm{Cu}$ and $\mathrm{Al}-$ $4.5 \mathrm{wt} \% \mathrm{Cu}$ alloys of $99.9 \%$ purity were purchased from Alusuisse SA (now Alcan; Neuhausen, Switzerland).

Reinforcing $\mathrm{Al}_{2} \mathrm{O}_{3}$ powders of two different types and with various average particle sizes were used. The first powder, purchased from Treibacher Schleifmittel (Laufenburg, Germany), is made of angular-shaped $\alpha$ $\mathrm{Al}_{2} \mathrm{O}_{3}$ particles. These contain micro-cracks identifiable under the Scanning Electron Microscope (SEM, Model Philips FEG XL30) [32,33]. Such powders are traditionally used in making MMCs. The average particle size, measured by centrifugal sedimentation on a "Horiba Capa-700" (Sulzbach, Germany) particle size analyzer, were $60,35,10$, and $5 \mu \mathrm{m}$ for the four lots investigated.

The second type of alumina powder, purchased from "Sumitomo Chemicals Co. Ltd." (Tokyo, Japan), is of polygonal shape, free of angular apexes, and contains no surface defects discernible under the SEM. The average particle sizes explored for the polygonal powders were 25,15 , and $5 \mu \mathrm{m}$.

The microstructural characteristics (particle type and size, volume fraction of the reinforcement, $V_{\mathrm{f}}$ and matrix alloy) of all composites tested in this work are summarized in Table 1. The nomenclature used to describe the composites (given in the last column of Table 1) follows that suggested by the Aluminium Association; however, the matrix is designated in full since it is not a commercial alloy $(\mathrm{Al}-2 \% \mathrm{Cu}$ and $\mathrm{Al}-4.5 \% \mathrm{Cu}$, it being understood that percentages are by weight), with suffixes 
Table 1

Summary of composites presented in this study and in [34]

\begin{tabular}{|c|c|c|c|c|}
\hline Matrix & $\begin{array}{l}\text { Reinforcement } \\
\text { type }\end{array}$ & $\begin{array}{l}\text { Average } \\
\text { reinforcement size }(\mu \mathrm{m})\end{array}$ & $V_{\mathrm{f}}(-)$ & $\begin{array}{l}\text { Composite designation } \\
\text { ( } X \text { stands for heat-treatment condition: } \mathrm{F}, \mathrm{T} 4 \text { or } \mathrm{T} 6)\end{array}$ \\
\hline $\mathrm{Al}-2 \% \mathrm{Cu}$ & $\begin{array}{l}\mathrm{Al}_{2} \mathrm{O}_{3} \text { angular } \\
\mathrm{Al}_{2} \mathrm{O}_{3} \text { angular } \\
\mathrm{Al}_{2} \mathrm{O}_{3} \text { angular } \\
\mathrm{Al}_{2} \mathrm{O}_{3} \text { angular }\end{array}$ & $\begin{array}{l}59 \pm 10 \\
33 \pm 8 \\
9.9 \pm 5 \\
3.7 \pm 1.5\end{array}$ & $\begin{array}{l}0.50 \\
0.47 \\
0.58 \\
0.41\end{array}$ & $\begin{array}{l}\mathrm{Al}-2 \% \mathrm{Cu} X / 60 \mu \mathrm{mAl}_{2} \mathrm{O}_{3} \mathrm{~A} / 50_{\mathrm{p}} \\
\mathrm{Al}-2 \% \mathrm{Cu} X / 35 \mu \mathrm{mAl}_{2} \mathrm{O}_{3} \mathrm{~A} / 47_{\mathrm{p}} \\
\mathrm{Al}-2 \% \mathrm{Cu} X / 10 \mu \mathrm{mAl}_{2} \mathrm{O}_{3} \mathrm{~A} / 58_{\mathrm{p}} \\
\mathrm{Al}-2 \% \mathrm{Cu} X / 5 \mu \mathrm{mAl}_{2} \mathrm{O}_{3} \mathrm{~A} / 41_{\mathrm{p}}\end{array}$ \\
\hline $\mathrm{Al}-4.5 \% \mathrm{Cu}$ & $\begin{array}{l}\mathrm{Al}_{2} \mathrm{O}_{3} \text { angular } \\
\mathrm{Al}_{2} \mathrm{O}_{3} \text { angular } \\
\mathrm{Al}_{2} \mathrm{O}_{3} \text { angular } \\
\mathrm{Al}_{2} \mathrm{O}_{3} \text { angular }\end{array}$ & $\begin{array}{l}59 \pm 10 \\
33 \pm 8 \\
9.9 \pm 5 \\
3.7 \pm 1.5\end{array}$ & $\begin{array}{l}0.52 \\
0.50 \\
0.58 \\
0.42\end{array}$ & $\begin{array}{l}\mathrm{Al}-4.5 \% \mathrm{Cu} X / 60 \mu \mathrm{mAl}_{2} \mathrm{O}_{3} \mathrm{~A} / 52_{\mathrm{p}} \\
\mathrm{Al}-4.5 \% \mathrm{Cu} X / 35 \mu \mathrm{mAl}_{2} \mathrm{O}_{3} \mathrm{~A} / 50_{\mathrm{p}} \\
\mathrm{Al}-4.5 \% \mathrm{Cu} X / 10 \mu \mathrm{mAl}_{2} \mathrm{O}_{3} \mathrm{~A} / 58_{\mathrm{p}} \\
\mathrm{Al}-4.5 \% \mathrm{Cu} X / 5 \mu \mathrm{mAl}_{2} \mathrm{O}_{3} \mathrm{~A} / 42_{\mathrm{p}}\end{array}$ \\
\hline $\mathrm{Al}-2 \% \mathrm{Cu}$ & $\begin{array}{l}\mathrm{Al}_{2} \mathrm{O}_{3} \text { polygonal } \\
\mathrm{Al}_{2} \mathrm{O}_{3} \text { polygonal } \\
\mathrm{Al}_{2} \mathrm{O}_{3} \text { polygonal }\end{array}$ & $\begin{array}{l}25 \pm 7 \\
15 \pm 4 \\
5.8 \pm 2\end{array}$ & $\begin{array}{l}0.59 \\
0.58 \\
0.57\end{array}$ & $\begin{array}{l}\mathrm{Al}-2 \% \mathrm{Cu} X / 25 \mu \mathrm{mAl}_{2} \mathrm{O}_{3} \mathrm{P} / 59_{\mathrm{p}} \\
\mathrm{Al}-2 \% \mathrm{Cu} X / 15 \mu \mathrm{mAl}_{2} \mathrm{O}_{3} \mathrm{P} / 58_{\mathrm{p}} \\
\mathrm{Al}-2 \% \mathrm{Cu} X / 5 \mu \mathrm{mAl}_{2} \mathrm{O}_{3} \mathrm{P} / 57_{\mathrm{p}}\end{array}$ \\
\hline $\mathrm{Al}-4.5 \% \mathrm{Cu}$ & $\begin{array}{l}\mathrm{Al}_{2} \mathrm{O}_{3} \text { polygonal } \\
\mathrm{Al}_{2} \mathrm{O}_{3} \text { polygonal } \\
\mathrm{Al}_{2} \mathrm{O}_{3} \text { polygonal }\end{array}$ & $\begin{array}{l}25 \pm 7 \\
15 \pm 4 \\
5.8 \pm 2\end{array}$ & $\begin{array}{l}0.60 \\
0.61 \\
0.58\end{array}$ & $\begin{array}{l}\mathrm{Al}-4.5 \% \mathrm{Cu} X / 25 \mu \mathrm{mAl}_{2} \mathrm{O}_{3} \mathrm{P} / 60_{\mathrm{p}} \\
\mathrm{Al}-4.5 \% \mathrm{Cu} X / 15 \mu \mathrm{mAl}_{2} \mathrm{O}_{3} \mathrm{P} / 61_{\mathrm{p}} \\
\mathrm{Al}-4.5 \% \mathrm{Cu} X / 5 \mu \mathrm{mAl}_{2} \mathrm{O}_{3} \mathrm{P} / 58_{\mathrm{p}}\end{array}$ \\
\hline
\end{tabular}

$V_{\mathrm{f}}$ : volume fraction of reinforcement; $X$ designates the heat-treatment: $\mathrm{F}$ for as-cast; T4 for solution treatment; T6 for peak-age.

"F" for as-cast, "T4" for solutionized and quenched, and "T6" for the T4 heat-treatment followed by aging at $100{ }^{\circ} \mathrm{C}$ to peak-hardness. The particles are designated with mention of their average size and type (using letters " $A$ " and "P" for angular and polygonal, respectively). As an example, "Al-4.5\% CuT4/15 $\mu \mathrm{mAl}_{2} \mathrm{O}_{3} \mathrm{P} / 61_{\mathrm{p}}$ " designates a composite with a matrix of $\mathrm{Al}-4.5 \mathrm{wt} \% \mathrm{Cu}$ that was solutionized and quenched, and which is reinforced with $61 \%$ polygonal alumina particles having an average size of $15 \mu \mathrm{m}$.

\subsection{Mechanical testing}

\subsubsection{Heat-treatment conditions}

In a preliminary study of the influence of heat treatment on the mechanical response of $\mathrm{Al}-2 \mathrm{wt} \% \mathrm{Cu}$ matrix composites [34], it was found that coarse intermetallics formed at the matrix/reinforcement interface during solidification are responsible for a strong toughness degradation. The composites are therefore studied here in three conditions:

- The as-cast condition ("F").

- The solutionized and quenched condition ("T4"). Full solutionization was obtained for both matrices by treatment at $515^{\circ} \mathrm{C}$ for at least $10 \mathrm{~h}$; this was followed by a quench of each sample in water. To minimize the progress of natural ageing during storage between quenching and mechanical testing, these samples were kept in a refrigerator at $-10{ }^{\circ} \mathrm{C}$ after quenching.

- Solutionization, quench and artificial aging to peak hardness at $100{ }^{\circ} \mathrm{C}$ ("T6"). Peak hardening times were determined experimentally, by treating a series of small composite coupons and measuring their hardness as a function of ageing time; the measured times for peak-hardening were in the range from 15 to $20 \mathrm{~h}$ for all composites. The relative increase in hardness upon peak-ageing (T6) compared with the solution treated and quenched (T4) condition was at most $15 \%$ for all composites. Hardness data can be found in [33].

\subsubsection{Tensile testing}

Tensile curves were measured on dogbone-shaped tensile specimens according to the ASTM B577M-84 procedure. The specimens were cut by electro-discharge machining (EDM). Tests were carried out on a $25 \mathrm{kN}$ hydraulic Instron (Canton, MA, USA) testing machine, at a nominal strain rate of $10^{-4} \mathrm{~s}^{-1}$. Longitudinal displacement was measured using a MTS (Minneapolis, MN, USA) clip-on extensometer, Model 632.13F-20. Young's modulus was determined after $0.1 \%$ of plastic deformation, by repeated unloading-reloading cycles according to the procedure described in [35].

\subsubsection{Fracture toughness measurement}

In contrast to the pure $\mathrm{Al}$ matrix composites, which necessitated the use of $J$-integral fracture testing due to their low yield stress, the fracture toughness of the present composites could be measured in small scale yielding (SSY) using chevron-notched specimens according to ASTM E-1304 [36]. With chevron-notched samples pre-cracking is unnecessary. This is attractive given the difficulty in pre-cracking such high volume fraction MMCs. 
Square-section short bar specimens, with a thickness $B$ of $18 \mathrm{~mm}$, were cut by EDM from the cast composites. A Zwick (Ulm, Germany) screw-driven universal testing machine was used for fracture testing. Tests were conducted in the crosshead displacement control mode, at $0.5 \mathrm{~mm} / \mathrm{min}$. The displacement was monitored using a "632.20c-20 MTS" (Minneapolis, USA) extensometer. Copper arms were used to measure the crack mouth opening displacement (CMOD) on the outside faces of the specimens.

Testing procedures and data analysis were conducted according to the method specified in the Standard; in particular the compliance method was employed to calculate the plane-strain fracture toughness, $K_{\mathrm{Iv}}$. Data gathered analogously from a preliminary study [34] are also reproduced hereafter to complete the present data. A minimum of two tests was performed for each material and heat-treatment condition, exception made for a few composites of low mechanical performance. Results presented below are the average of all measures for a given material and heat-treatment condition; standard deviations are given in tables below and also as error bars on graphs.

A few composites were additionally tested by $J$ integral testing, according to ASTM E-1737, as in [15] using the same pre-cracking procedure (described in [33]). $J-R$ curves were measured with the single-specimen method, using the compliance method to compute the crack length. The critical fracture parameter was taken at the initiation of ductile tearing according to the method described in [15].

\subsection{Identification of the micromechanisms of fracture}

\subsubsection{Crack profiles}

The arrested-crack technique described in $[15,34]$ was used to identify the micromechanisms of fracture in all composites. The portion of fracture surfaces covered by broken particles, $f_{\mathrm{b}}$ was measured by manually counting the number of broken particles along the crack paths. About 15-20 optical micrographs - taken at appropriate magnifications to identify the failures modes of the different particle size composites - were used. The total crack length was also computed for these micrographs by taking into account crack deflection on each picture.

\subsubsection{SEM fractography and digital reconstruction of fracture surfaces}

In fractographic examination, using the backscattered electron mode of the SEM, microcavities nucleated by secondary intermetallic phases can be distinguished from microcavities nucleated between intact particles or by cracked particles. Fracture surfaces of a few composite specimens were also numerically reconstructed in three-dimensions, using the MEX software [37] as in
[15]. The average dimple height was then computed from these numerically reconstructed fractographs.

\section{Results}

\subsection{Microstructure}

\subsubsection{The reinforcement}

A typical optical micrograph of a polygonal particle reinforced composite $\left(\mathrm{Al}-2 \% \mathrm{Cu} / 15 \mu \mathrm{mAl}_{2} \mathrm{O}_{3} \mathrm{P} / 58_{\mathrm{p}}\right)$ is shown in Fig. 1(a). The particles are tightly packed with a homogeneous spatial distribution throughout each composite. There is some variation in the reinforcement volume fraction, $V_{\mathrm{f}}$ from one composite to another, particularly with angular alumina (Table 1). This is because the volume fraction ceramic in infiltrated composites is the natural packing volume fraction of the particles, which varies with the particle type because it depends on characteristics such as the particle shape and size distribution (particles were not cold-pressed as this may lead to particle indentation and fracture). Overall, the following trends are seen:

(i) all polygonal particle reinforced composites contain roughly the same volume fraction ceramic (between 57 and $61 \mathrm{vol} \%$ ); there is thus no influence expected of the volume fraction ceramic in these composites;

(ii) with angular alumina particles, the smallest $(5 \mu \mathrm{m})$ particles stand out as producing the lowest volume fraction ceramic (41-42 vol\%). Larger particles produce volume fractions closer to, albeit still somewhat lower than, what is found with polygonal particles (from 47 to $58 \mathrm{vol} \%$ ).

\subsubsection{The matrix}

In as-cast composites, all particles are surrounded by numerous coarse intermetallic phases formed during matrix solidification, Fig. 1(b). These images complement those previously reported in [34] for $\mathrm{Al}-2 \% \mathrm{Cu}$ matrix composites; the amount of intermetallic is clearly higher with $4.5 \% \mathrm{Cu}$ in the matrix. After heat-treatment to the T4 condition, Fig. 1(c), most of these coarse intermetallic phases are dissolved; however, a residual amount remains. This is due to the presence of $\mathrm{Fe}$ as a trace element in the matrix, which forms stable $\mathrm{Al}-\mathrm{Cu}-\mathrm{Fe}$ precipitates that are not dissolved after heat-treatment [34].

\subsection{Tensile curves}

The influence of matrix $\mathrm{Cu}$ alloying on the tensile characteristics is dependent on the particle type. With angular reinforcements, the tensile response becomes increasingly brittle as the matrix $\mathrm{Cu}$ content increases. 
(a)

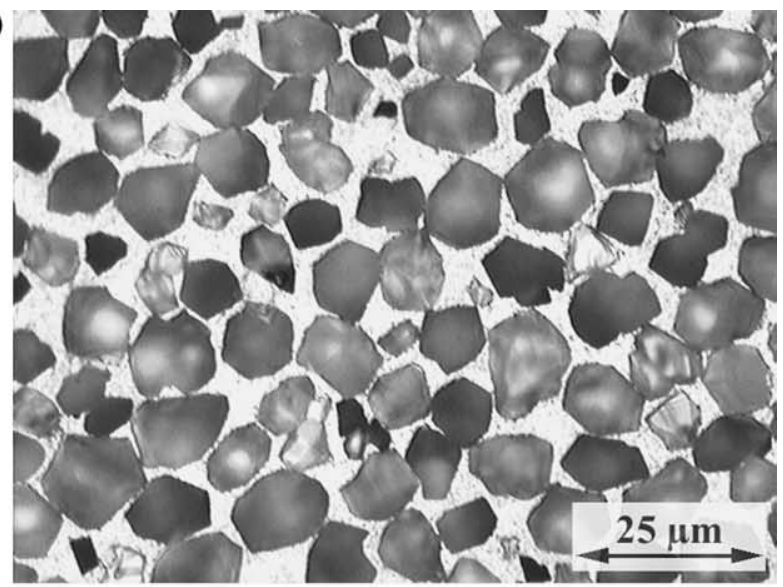

(b)

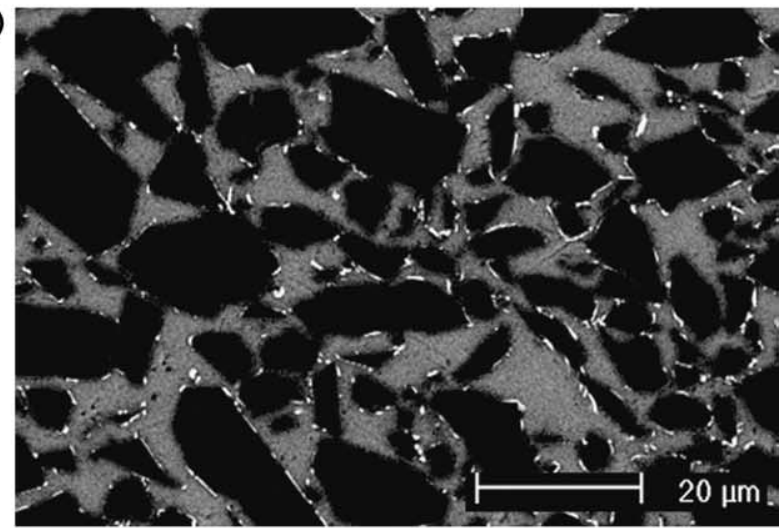

(c)

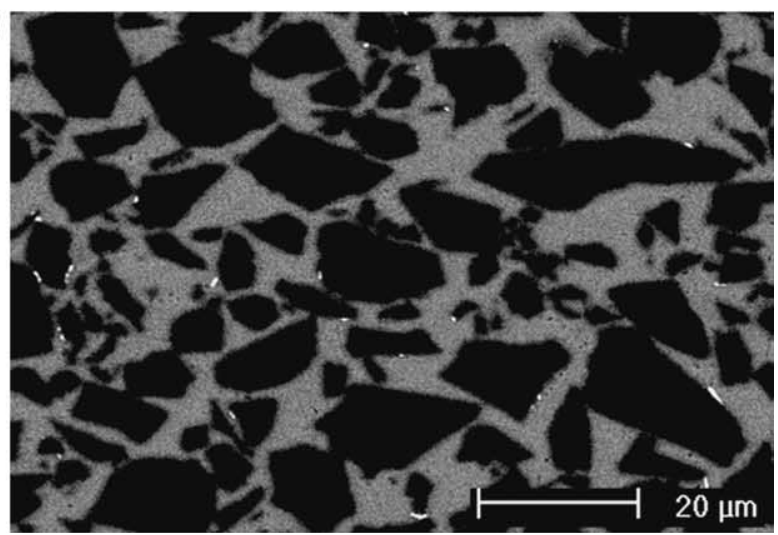

Fig. 1. Microstructures of the composites. (a) $\mathrm{Al}-2 \% \mathrm{Cu} / 15 \mu \mathrm{mAl} \mathrm{O}_{2} \mathrm{O}_{3} \mathrm{P} /$ $59_{\mathrm{p}}$, optical micrograph; (b) $\mathrm{Al}-4.5 \% \mathrm{CuF} / 10 \mu \mathrm{mA} / 58_{\mathrm{p}}$ (as-cast), SEM micrograph in BSE detector mode (showing secondary phases at particle/matrix interfaces); (c) $\mathrm{Al}-4.5 \% \mathrm{CuT} 4 / 10 \mu \mathrm{mA} / 58_{\mathrm{p}}$ (solution treated), SEM micrograph in BSE mode: nearly all intermetallic phases are dissolved.

This is illustrated for the $35 \mu \mathrm{m}$ particle size reinforced composites in Fig. 2(a), which includes data for a pure Al matrix from [32]. Heat-treatment improves the tensile response; however, no significant difference is found between T4 and T6 conditions, Fig. 2(a).

Similar variations are also found with polygonal reinforcements; however, the composite tensile elongations at fracture remain near or above $1 \%$ with these higher-
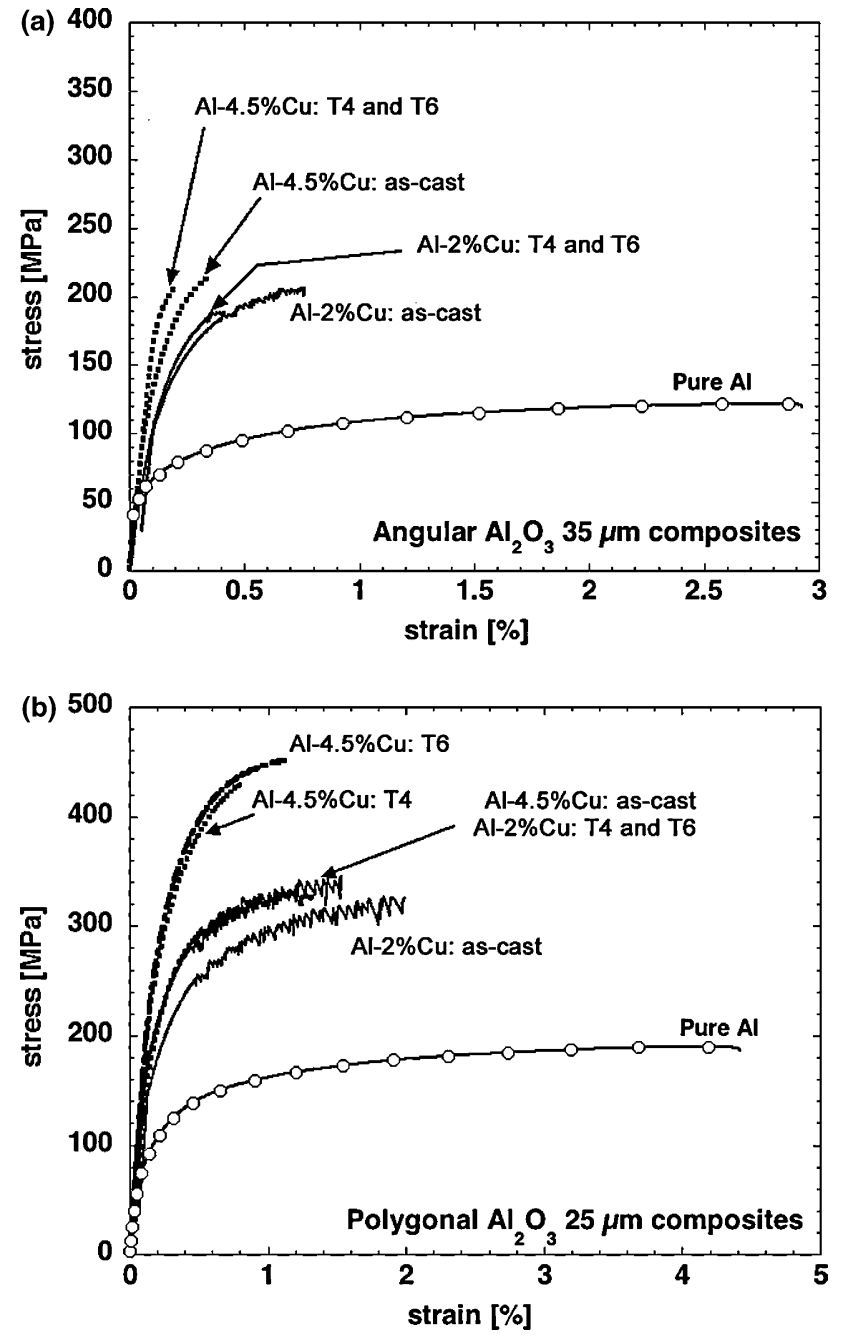

Fig. 2. Tensile behaviour of $\mathrm{Al}-\mathrm{Cu}$ matrix composites. (a) angular $35 \mu \mathrm{m}$ reinforced composites, illustrating embrittlement of the composites as the $\mathrm{Cu}$ content in the matrix increases; (b) polygonal $25 \mu \mathrm{m}$ reinforced composites: the composite flow stress increases as the $\mathrm{Cu}$ content increases and significant plastic deformation is still observed.

performance reinforcements: a tensile elongation in the range $1.5-2 \%$ is for instance measured with the $\mathrm{Al}-$ $2 \% \mathrm{CuT} 4 / 25 \mu \mathrm{mAl}_{2} \mathrm{O}_{3} \mathrm{P} / 59_{\mathrm{p}}$ composite in all three heattreatment conditions, Fig. 2(b). As can be seen on the same plot, flow stresses are higher with $4.5 \% \mathrm{Cu}$ in the matrix; at the same time the strain to fracture decreases to around $1 \%$ for heat-treated materials. Load instabilities are also seen on the stress-strain curves of Fig. 2(b), these are a manifestation of the Portevin-Le Chatelier effect [38-40], which is also detected in the similarly processed unreinforced $\mathrm{Al}-\mathrm{Cu}$ matrices of these composites. More tensile data for these materials can be found in [33]. These and other, more recent, data indicate in particular that the influence of dislocation emission during composite cooldown from processing temperatures is significantly less pronounced with an $\mathrm{Al}-\mathrm{Cu}$ than with a pure $\mathrm{Al}$ matrix. 


\subsection{Fracture toughness}

\subsubsection{Influence of the matrix composition and heat- treatment}

A full listing of chevron-notch fracture toughness data (fracture toughness $K_{\mathrm{Iv}}$ and plasticity criterion parameter $p$ ) is given in Table 2 .

For a given reinforcement type, the toughness is strongly influenced by solution heat-treatment; it is, on the other hand, practically unaffected by subsequent peak-ageing. This is illustrated in Fig. 3(a) for the Al$4.5 \% \mathrm{Cu} / 25 \mu \mathrm{mAl}_{2} \mathrm{O}_{3} \mathrm{P} / 60_{\mathrm{p}}$ composite, where typical load-displacement plots of chevron-notched sample tests are presented for all three heat-treatment conditions. Such differences - previously reported for $\mathrm{Al}-$ $2 \% \mathrm{Cu}$ matrix composites [34] - are magnified with $\mathrm{Al}-4.5 \% \mathrm{Cu}$.

Once the matrix has been solutionized to form a single solid-solution phase, the fracture toughness of the composites is found to increase with increasing matrix $\mathrm{Cu}$ content. Strength and toughness can thus increase together in these materials when they are optimally heat-treated. An illustration of this behaviour is presented by the raw data in Fig. 3(b) for $10 \mu \mathrm{m}$ angular reinforced composites; similar results were obtained with polygonal particle reinforced composites.

\subsubsection{Validity criteria and comparison with J-integral tests}

The specimen size requirement was fulfilled for all composites except $\mathrm{Al}-2 \% \mathrm{CuT} 4 / 15 \mu \mathrm{mAl}_{2} \mathrm{O}_{3} \mathrm{P} / 58_{\mathrm{p}}$ and $\mathrm{Al}-2 \% \mathrm{CuT} 6 / 15 \mu \mathrm{mAl}_{2} \mathrm{O}_{3} \mathrm{P} / 58_{\mathrm{p}}$; for these two composites the deviation remained small (around 10\%).

(i) As-cast materials. A second requirement is formulated in terms of parameter $p$ defined in the ASTM Norm $(-0.05<p<0.1)$; a closer examination of its significance (and limitations) is given in [41]. This requirement was systematically violated in the as-cast condition $(\mathrm{F})$, for both angular and polygonal particles: $p$ values range from 0.15 to 0.40 , Table 2 . Parameter $p$ values larger than 0.1 are in principle an indication of excessive plasticity, causing the measured toughness to be overestimated. This is, however, obviously not realistic here, for the following reasons. First, angular particle reinforced composites - for which the $p$ value also exceeds 0.2 - have an almost fully brittle tensile behavior with elongations to failure, $\varepsilon_{\mathrm{f}}$ as small as $0.1 \%$ (Fig. 2(a)). It is therefore unlikely that large-scale yielding has occurred in such composites, as also confirmed experimentally in [42]. As a comparison, for tough unreinforced $\mathrm{Al}$ alloys for which large values of $p$ are reported, tensile elongations are in the range of $10 \%$. Secondly, a high $p$-value is an indication of a relatively tough material, while as-cast composites are the least tough composites tested in this study. The large values of $p$ must therefore be attributed to the build-up of extensive damage in
Table 2

Average value and standard deviation of fracture toughness for each composite

\begin{tabular}{|c|c|c|c|}
\hline Composite & $\begin{array}{l}\text { Heat treatment } \\
\text { condition }\end{array}$ & $\begin{array}{l}K_{\mathrm{Iv}} \\
(\mathrm{MPa} \sqrt{ } \mathrm{m})\end{array}$ & $p(-$ \\
\hline \multirow[t]{3}{*}{$\mathrm{Al}-2 \% \mathrm{Cu} / 60 \mu \mathrm{mAl}{ }_{2} \mathrm{O}_{3} \mathrm{~A} / 50_{\mathrm{p}}$} & $\mathrm{F}$ & 14 & \\
\hline & $\mathrm{T} 4$ & $17.5 \pm 0.5$ & \\
\hline & T6 & $16.8 \pm 1$ & 0.2 \\
\hline \multirow[t]{3}{*}{$\mathrm{Al}-2 \% \mathrm{Cu} / 35 \mu \mathrm{mAl}{ }_{2} \mathrm{O}_{3} \mathrm{~A} / 47_{\mathrm{p}}$} & $\mathrm{F}$ & $19.1 \pm 0.5$ & 0 . \\
\hline & $\mathrm{T} 4$ & $23.7 \pm 1$ & 0. \\
\hline & T6 & $23.1 \pm 1$ & 0 . \\
\hline \multirow[t]{3}{*}{$\mathrm{Al}-2 \% \mathrm{Cu} / 10 \mu \mathrm{mAl}{ }_{2} \mathrm{O}_{3} \mathrm{~A} / 58_{\mathrm{p}}$} & $\mathrm{F}$ & $14.5 \pm 0.5$ & \\
\hline & $\mathrm{T} 4$ & $24.1 \pm 0.5$ & -0 . \\
\hline & T6 & $23.3 \pm 0.5$ & -0 \\
\hline \multirow[t]{3}{*}{$\mathrm{Al}-2 \% \mathrm{Cu} / 5 \mu \mathrm{mAl}{ }_{2} \mathrm{O}_{3} \mathrm{~A} / 41_{\mathrm{p}}$} & $\mathrm{F}$ & 13 & 0. \\
\hline & $\mathrm{T} 4$ & $20.2 \pm 0.5$ & -0 . \\
\hline & T6 & $19.9 \pm 1$ & -0 \\
\hline \multirow[t]{3}{*}{$\mathrm{Al}-4.5 \% \mathrm{Cu} / 60 \mu \mathrm{mAl}_{2} \mathrm{O}_{3} \mathrm{~A} / 52_{\mathrm{p}}$} & $\mathrm{F}$ & $11.4 \pm 0.5$ & 0 \\
\hline & $\mathrm{T} 4$ & $17.7 \pm 1.5$ & 0. \\
\hline & T6 & $18.7 \pm 0.5$ & 0.2 \\
\hline \multirow[t]{3}{*}{$\mathrm{Al}-4.5 \% \mathrm{Cu} / 35 \mu \mathrm{mAl}{ }_{2} \mathrm{O}_{3} \mathrm{~A} / 50_{\mathrm{p}}$} & $\mathrm{F}$ & $16.9 \pm 0.1$ & 0. \\
\hline & $\mathrm{T} 4$ & $25.6 \pm 0.5$ & 0. \\
\hline & T6 & $24.3 \pm 0.5$ & 0. \\
\hline \multirow[t]{3}{*}{$\mathrm{Al}-4.5 \% \mathrm{Cu} / 10 \mu \mathrm{mAl}{ }_{2} \mathrm{O}_{3} \mathrm{~A} / 58_{\mathrm{p}}$} & $\mathrm{F}$ & $13.4 \pm 0.5$ & 0.12 \\
\hline & $\mathrm{T} 4$ & $27.6 \pm 0.5$ & -0.3 \\
\hline & T6 & $25.4 \pm 0.5$ & 0.0 \\
\hline \multirow[t]{3}{*}{$\mathrm{Al}-4.5 \% \mathrm{Cu} / 5 \mu \mathrm{mAl} \mathrm{O}_{3} \mathrm{~A} / 42_{\mathrm{p}}$} & $\mathrm{F}$ & $12.4 \pm 0.5$ & 0.0 \\
\hline & $\mathrm{T} 4$ & $23.5 \pm 0.5$ & -0.5 \\
\hline & T6 & $22.7 \pm 0.5$ & -0.5 \\
\hline \multirow[t]{3}{*}{$\mathrm{Al}-2 \% \mathrm{Cu} / 25 \mu \mathrm{mAl}_{2} \mathrm{O}_{3} \mathrm{P} / 59_{\mathrm{p}}$} & $\mathrm{F}$ & $23.2 \pm 0.5$ & 0.3 \\
\hline & $\mathrm{T} 4$ & $32.9 \pm 0.5$ & 0. \\
\hline & T6 & $32.5 \pm 0.5$ & 0.1 \\
\hline \multirow[t]{3}{*}{$\mathrm{Al}-2 \% \mathrm{Cu} / 15 \mu \mathrm{mAl}_{2} \mathrm{O}_{3} \mathrm{P} / 58_{\mathrm{p}}$} & $\mathrm{F}$ & $23.3 \pm 0.5$ & 0. \\
\hline & $\mathrm{T} 4$ & $31.2 \pm 0.5$ & 0. \\
\hline & T6 & $30.9 \pm 0.5$ & 0.1 \\
\hline \multirow[t]{3}{*}{$\mathrm{Al}-2 \% \mathrm{Cu} / 5 \mu \mathrm{mAl}_{2} \mathrm{O}_{3} \mathrm{P} / 57_{\mathrm{p}}$} & $\mathrm{F}$ & $18.5 \pm 1.5$ & $0.2^{-}$ \\
\hline & $\mathrm{T} 4$ & $24.8 \pm 0.5$ & -0.1 \\
\hline & T6 & $26.2 \pm 1$ & -0.1 \\
\hline \multirow[t]{3}{*}{$\mathrm{Al}-4.5 \% \mathrm{Cu} / 25 \mu \mathrm{mAl}{ }_{2} \mathrm{O}_{3} \mathrm{P} / 60_{\mathrm{p}}$} & $\mathrm{AC}$ & $17.3 \pm 0.5$ & 0.2 \\
\hline & $\mathrm{T} 4$ & $33.3 \pm 1$ & -0.16 \\
\hline & T6 & $33.3 \pm 0.5$ & -0.2 \\
\hline \multirow[t]{3}{*}{$\mathrm{Al}-4.5 \% \mathrm{Cu} / 15 \mu \mathrm{mAl}{ }_{2} \mathrm{O}_{3} \mathrm{P} / 61_{\mathrm{p}}$} & $\mathrm{F}$ & $18.6 \pm 0.5$ & 0.1 \\
\hline & $\mathrm{T} 4$ & $33.7 \pm 0.5$ & -0.2 \\
\hline & T6 & $33.7 \pm 0.5$ & -0.3 \\
\hline \multirow[t]{3}{*}{$\mathrm{Al}-4.5 \% \mathrm{Cu} / 5 \mu \mathrm{mAl}_{2} \mathrm{O}_{3} \mathrm{P} / 58_{\mathrm{p}}$} & $\mathrm{F}$ & $14.7 \pm 0.5$ & $0.0^{7}$ \\
\hline & $\mathrm{T} 4$ & $29.2 \pm 0.5$ & -0.12 \\
\hline & T6 & 30 & \\
\hline
\end{tabular}

$K_{\mathrm{Iv}}$ is the plane strain chevron-notched fracture toughness and $p$ relates to the plasticity criterion of the chevron-notched test. Except where there is no standard deviation indicated (where only one sample was tested), values are averages of at least two measures. 

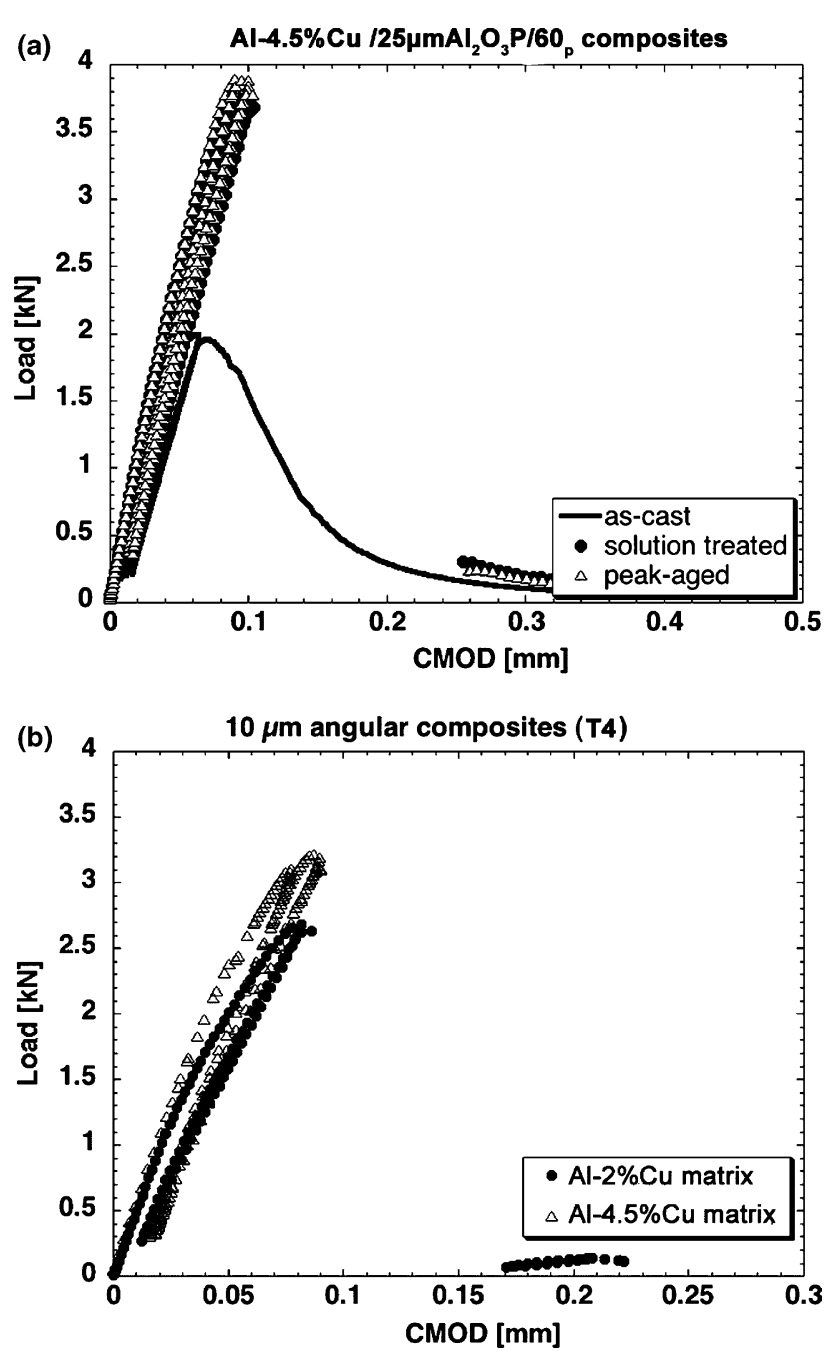

Fig. 3. Typical chevron notch fracture test curves. (a) $\mathrm{Al}-4.5 \% \mathrm{Cu} / 25$ $\mu \mathrm{mAl}_{2} \mathrm{O}_{3} \mathrm{P} / 60_{\mathrm{p}}$ composites at various heat-treatments; (b) angular $10 \mu \mathrm{m}$ reinforced composites, with $\mathrm{Al}-2 \% \mathrm{Cu}$ and $\mathrm{Al}-4.5 \% \mathrm{Cu}$ matrix, in $\mathrm{T} 4$ conditions.

front of the crack-tip, which can indeed cause an irreversible crack opening after unloading. We thus conclude that the high $p$ values are not indicative of excessive plasticity in the as-cast samples.

(ii) Heat-treated materials. For tougher heat-treated composites, on the other hand, $p$ was often negative indicating the presence of residual stresses [43]. Since the residual stresses are most likely due to quenching, they must be tensile in the middle of the specimens (and hence in the chevron-notch). They therefore tend to decrease the apparent toughness. Other comparative and extensive studies between the chevron-notched test and the ASTM E-399 procedure on a variety of Al alloys [44] have also concluded that: (i) both methods provide an equivalent measure up to $35 \mathrm{MPa} \sqrt{ } \mathrm{m}$ and (ii) both remain close for values of $K_{\mathrm{Ic}}$ as high as $55 \mathrm{MPa} \sqrt{ } \mathrm{m}$, relative deviations being about $10 \%$. The measured values are hence considered to be close to $K_{\text {Ic }}$, the plane-strain fracture toughness.

Consistency was verified by comparing the toughness data with those from $J$-integral tests on CT specimens of the same material. $J-R$ curves of two composites $\left(\mathrm{Al}-2 \% \mathrm{CuT} 4 / 35 \quad \mu \mathrm{mAl}_{2} \mathrm{O}_{3} \mathrm{~A} / 47_{\mathrm{p}}\right.$ and $\mathrm{Al}-2 \% \mathrm{CuT} 4 / 15$ $\left.\mu \mathrm{mAl}_{2} \mathrm{O}_{3} \mathrm{P} / 58_{\mathrm{p}}\right)$ are presented in Fig. 4. In the angular reinforced composite, a small degree of crack advance and damage occur prior to catastrophic fracture, but in contrast to their pure $\mathrm{Al}$ counterparts [15] no ductile tearing is noticed. Limited ductile tearing is on the other hand observed with polygonal reinforcements. The fracture toughness $K_{\text {Jeq }}$ is then obtained by converting the value of $J$ at catastrophic fracture into its equivalent stress intensity factor (note that $J$ fracture tests were not strictly valid due to excessive crack-front curvature after fatigue pre-cracking). In polygonal particle composites, some degree of ductile tearing occurs after process zone formation.

As was justified in [15], the $J$ value at initiation of tearing can be identified with the critical fracture event, and then converted into the corresponding plane-strain critical stress-intensity factor. These values are compared with those obtained from chevron-notch specimens $\left(K_{\mathrm{IV}}\right)$ on various composites in Table 3 . As seen, $K_{\text {IV }}$ data are somewhat higher (by $10 \%$ or less for three composite types, by $30 \%$ for one). This is expected for materials featuring significant $R$-curve behaviour [45], since in chevron-notch testing the critical toughness is measured after a significant degree of crack advance. The two measurements are hence not fully equivalent in nature; however, the difference remains relatively

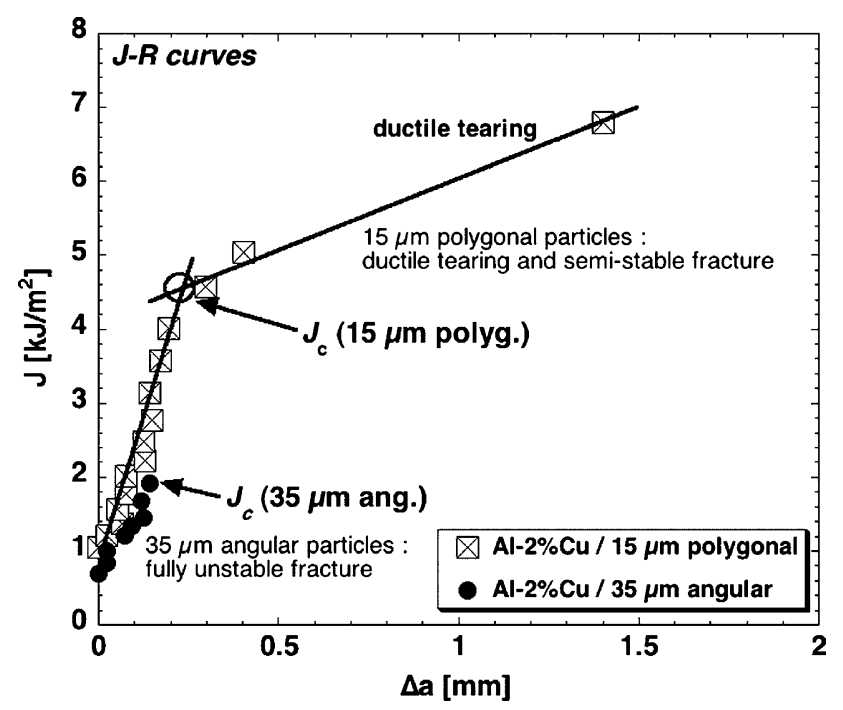

Fig. $4 . J$ vs. $\Delta a$ curves of the $\mathrm{Al}-2 \% \mathrm{CuT} 4 / 35 \mu \mathrm{mAl}_{2} \mathrm{O}_{3} \mathrm{~A} / 47_{\mathrm{p}}$ and the $\mathrm{Al}-2 \% \mathrm{CuT} 4 / 15 \mu \mathrm{mAl}_{2} \mathrm{O}_{3} \mathrm{P} / 58_{\mathrm{p}}$ composites. Fracture is fully unstable in the former, whereas some ductile tearing is detected in the latter. Critical fracture is taken at instability ( $\mathrm{Al}-2 \% \mathrm{CuT} 4 / 35 \mu \mathrm{mAl}_{2} \mathrm{O}_{3} \mathrm{~A} / 47_{\mathrm{p}}$ ) or at the onset of ductile tearing ( $\mathrm{Al}-2 \% \mathrm{CuT} 4 / 15 \mu \mathrm{mAl}_{2} \mathrm{O}_{3} \mathrm{P} / 58_{\mathrm{p}}$ ), see [15]. 
Table 3

Comparison between toughness values as measured by: (i) chevron-notched fracture testing ( $\left.K_{\text {Iv }}\right)$ and (ii) $J$-integral fracture testing with values converted into their equivalent critical stress-intensity factors $\left(K_{\text {Jeq }}\right)$ as described in [34]. For the latter $(J$-integral) data, excessive crack front curvature did not allow to fully validate the data according to the standard. In the latter series, three specimens were tested for the $\mathrm{Al}-2 \% \mathrm{Cu} \mathrm{T} 4 /$ $15 \mu \mathrm{mAl}_{2} \mathrm{O}_{3} \mathrm{P} / 58_{\mathrm{p}}$ composite; one for each of the remaining three composites

\begin{tabular}{llll}
\hline Composite & $\begin{array}{l}\mathrm{Al}-2 \% \mathrm{Cu} \mathrm{T} 4 / 15 \\
\mu \mathrm{mAl}_{2} \mathrm{O}_{3} \mathrm{P} / 58_{\mathrm{p}}\end{array}$ & $\begin{array}{l}\mathrm{Al}-2 \% \mathrm{Cu} \mathrm{T} 4 / 60 \\
\mu \mathrm{mAl}{ }_{2} \mathrm{O}_{3} \mathrm{~A} / 50_{\mathrm{p}}\end{array}$ & $\begin{array}{l}\mathrm{Al}-2 \% \mathrm{Cu} \mathrm{T} 4 / 35 \\
\mu \mathrm{mAl}-4.5 \% \mathrm{Cu} \mathrm{F} / 35\end{array}$ \\
\hline$K_{\mathrm{Iv}}(\mathrm{MPa} \sqrt{ } \mathrm{m})$ & $31.2 \pm 0.5$ & $17.5 \pm 0.5$ & $23.7 \pm 1$ \\
$K_{\mathrm{Jeq}}(\mathrm{MPa} \sqrt{ })$ & $28.4 \pm 0.5$ & 16.5 & $16.9 \pm 0.1$ \\
\hline
\end{tabular}

low, confirming that the two data sets are consistent. This is because the $R$-curve behaviour is not very pronounced after the onset of ductile tearing as defined in [15].

\subsubsection{Data summary}

The following trends emerge from the present toughness data, plotted in Fig. 5 in terms of fracture toughness $K_{\mathrm{Iv}}$ vs. particle size for the various heat-treatment conditions (Fig. 5(a), (c) and (e)):

(i) As-cast composites are all less tough than corresponding heat-treated composites; compare Fig. 5(a) with Fig. 5(c) and (e). The difference between the as-cast and heat-treated conditions is amplified as the $\mathrm{Cu}$ matrix content increases.

(ii) In the T4 and T6 conditions, the toughness increases slightly when the $\mathrm{Cu}$ concentration in the matrix rises from $2 \%$ to $4.5 \%$, Fig. 5(c) and (e). At the same time the composite yield and tensile strengths are also enhanced, Fig. 2: strength and toughness increase simultaneously with alloying after heat-treatment.

(iii) Peak-aging after solutionization does not affect the toughness significantly (compare Fig. 5(c) and (e)).

(iv) In angular particle composites, after heattreatment the toughness increases as the average particle size increases from 5 to $10 \mu \mathrm{m}$, for which a peak value is obtained, Fig. 5(c) and (e).

(v) In all heat-treatment conditions (F, T4 and T6), for all particle sizes and for both alloyed matrices, polygonal particle composites are significantly tougher than corresponding angular particle composites, Fig. 5(a), (c) and (e).

(vi) Within experimental error, the toughness of polygonal particle reinforced composites increases with increasing average particle size for the range of sizes explored here, Fig. 5(a), (c) and (e). A slight difference is, however, noticed depending on the $\mathrm{Cu}$ content: while the toughness rises in $\mathrm{Al}-2 \% \mathrm{Cu}$ matrix composites as the particle size is increased from 15 to $25 \mu \mathrm{m}$, it remains roughly constant with $\mathrm{Al}-4.5 \% \mathrm{Cu}$.

(vii) Although this is not the only relevant parameter, it can be noted that increasing toughness does not come with decreasing volume fraction ceramic (Fig. 5(a), (c) and (e) and Table 2):
- $5 \mu \mathrm{m}$ angular particle composites, which contain only around $41 \mathrm{vol} \%$ ceramic, are among the most brittle;

- $10 \mu \mathrm{m}$ angular particle composites are the toughest among angular composites in both T4 and T6 conditions, Fig. 5(c) and (e); yet, they have the highest volume fraction ceramic of all angular particle composites (58\%, Table 1);

- Polygonal particle composites contain the most ceramic $(59 \pm 2 \mathrm{vol} \%)$ yet these are systematically tougher than angular composites.

The influence of particle volume fraction on composite toughness is thus minor in comparison with that of other parameters such as particle size, matrix composition and heat-treatment condition, or particle quality.

\subsection{Micromechanisms of fracture}

\subsubsection{Crack profiles}

Crack profiles along crack paths and in the crack-tip process zone are presented in Fig. 6. In angular particle composites with average particle sizes of 10,35 , and $60 \mu \mathrm{m}$, particle cracking is clearly dominant regardless of $\mathrm{Cu}$ concentration and heat-treatment, Fig. 6(a) and (b). The fraction of the crack path occupied by broken particles, $f_{\mathrm{b}}$ is reported in Fig. 5(b), (d) and (f). Note that the $10 \mathrm{~m}$ particle size composites feature larger values of $f_{\mathrm{b}}$ because their volume fraction of particles is higher: in a composite where all particles are broken along the crack path $f_{\mathrm{b}}$ will clearly be higher if the ceramic content is also higher. In the small $(5 \mu \mathrm{m})$, angular particle reinforced composites, the crack propagates with a roughly equal level of particle cracking and matrix voiding. In these composites, a precise determination of $f_{\mathrm{b}}$ necessitated the use of SEM fractographs to overcome resolution limitations of optical microscopy.

In polygonal particle composites the dominant mode of failure varies with the $\mathrm{Cu}$ content and with the heattreatment condition. In $15 \mu \mathrm{m}$ polygonal particle reinforced $\mathrm{Al}-2 \% \mathrm{Cu}$, matrix voiding is the dominant mode of failure at all heat-treatment conditions, Fig. 6(c). As the $\mathrm{Cu}$ content increases to $4.5 \%$, the fraction of broken particles along the crack path increases. In the peakaged condition, nearly one-half of the crack path is occupied by broken particles, Figs. 6(d) and 5(f). 

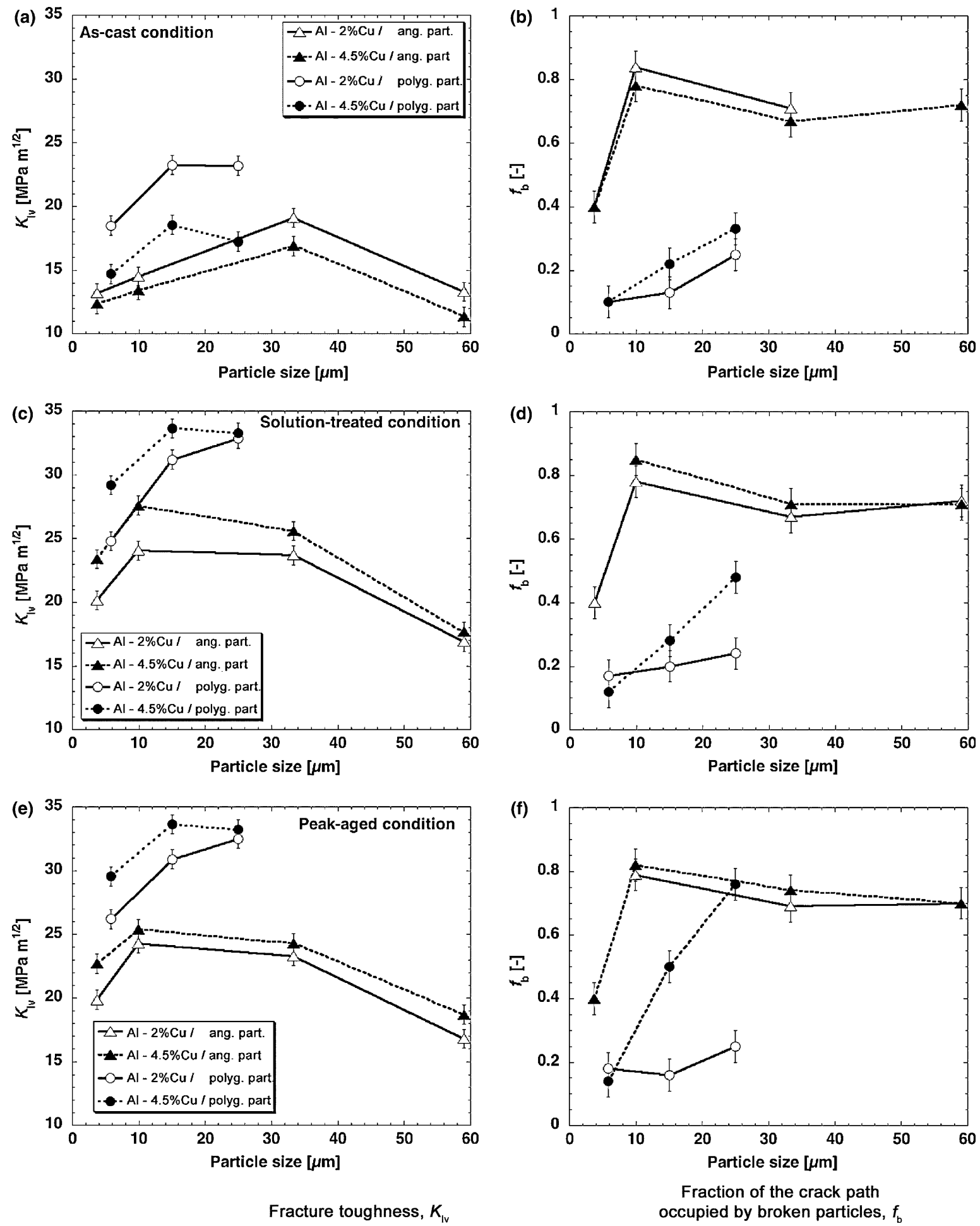

Fraction of the crack path occupied by broken particles, $f_{\mathrm{b}}$

Fig. 5. Plane-strain chevron-notch toughness $\left(K_{\mathrm{IV}}\right)$ vs. average reinforcement size for the different composites, and corresponding values of the fraction of crack paths occupied by broken particles, $f_{\mathrm{b}}$. (a) and (b) as-cast (F) composites; (c) and (d) solution-treated (T4) composites; (e) and (f) peak-aged (T6) composites.

This transition in fracture micromechanisms is also evident in the polygonal $25 \mu \mathrm{m}$ alumina reinforced composites. With $\mathrm{Al}-2 \% \mathrm{Cu} f_{\mathrm{b}}$ is around $25 \%$ at all heat-treatment conditions, Fig. 5(b), (d) and (f). With $\mathrm{Al}-4.5 \% \mathrm{Cu} f_{\mathrm{b}}$ increases and becomes dependent on the heat-treatment: in as-cast composites matrix voiding is the dominant failure mode (Fig. 5(b)), while in the solution-treated composite particle cracking and matrix cavitation occur at roughly equivalent levels (Fig. 5(d)). In the T6 condition particle cracking is dominant: here all 
(a)

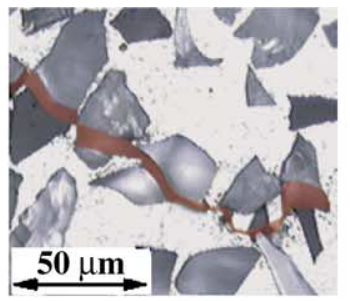

(b)

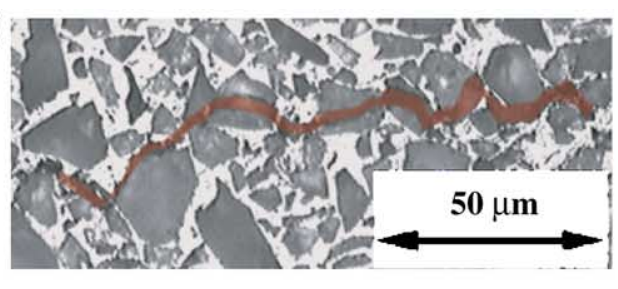

All particles broken along the crack path

(c)

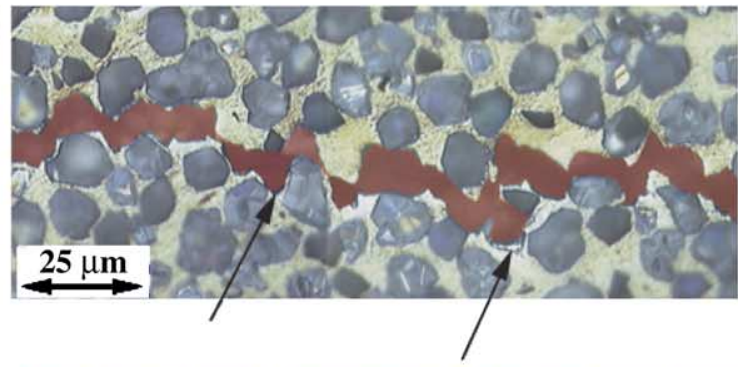

(d)

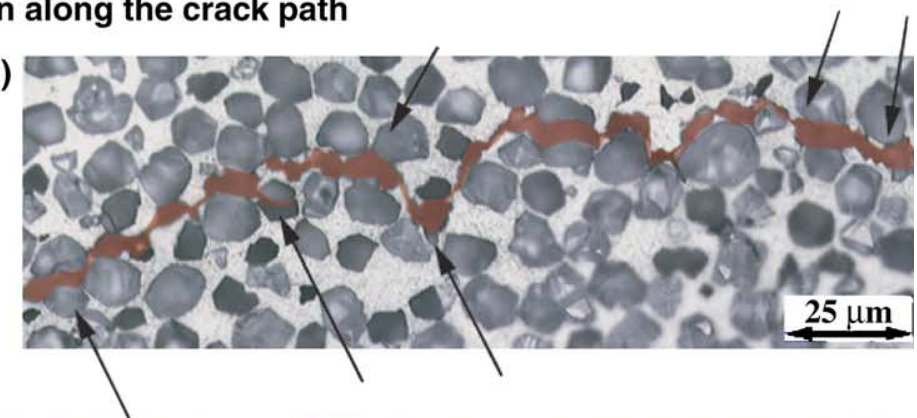

(e)

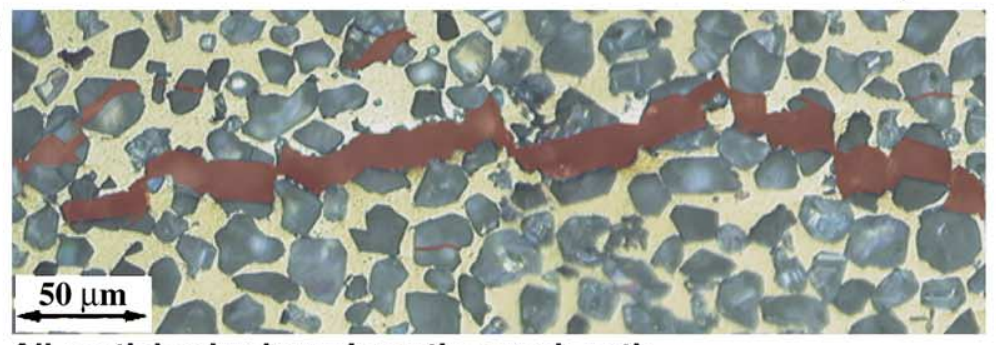

(f)

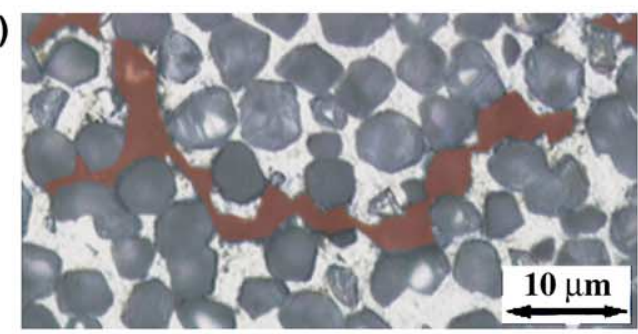

All particles broken along the crack path

Fig. 6. Crack profiles of the composites, from arrested chevron-notched specimens. (a) $\mathrm{Al}-2 \% \mathrm{CuT} 4 / 35 \mu \mathrm{mAl}{ }_{2} \mathrm{O}_{3} \mathrm{~A} / 47_{\mathrm{p}} ;$ (b) $\mathrm{Al}-2 \% \mathrm{CuF} / 10$ $\mu \mathrm{mAl}{ }_{2} \mathrm{O}_{3} \mathrm{~A} / 58_{p}$; (c) $\mathrm{Al}-2 \% \mathrm{CuT} 4 / 15 \mu \mathrm{mAl}_{2} \mathrm{O}_{3} \mathrm{P} / 58_{\mathrm{p}}$; (d) $\mathrm{Al}-4.5 \% \mathrm{CuT} 6 / 15 \mu \mathrm{mAl}_{2} \mathrm{O}_{3} \mathrm{P} / 61_{\mathrm{p}}$; (e) $\mathrm{Al}-4.5 \% \mathrm{CuT} 6 / 25 \mu \mathrm{mAl}_{2} \mathrm{O}_{3} \mathrm{P} / 60_{\mathrm{p}}$; (f) $\mathrm{Al}-4.5 \% \mathrm{CuT} 4 / 5$ $\mu \mathrm{mAl}_{2} \mathrm{O}_{3} \mathrm{P} / 58$. Note in particular for the $15 \mu \mathrm{m}$ and the $25 \mu \mathrm{m}$ polygonal reinforced composites that the amount of broken particles increases as the matrix is strengthened (high $\mathrm{Cu}$ content and $\mathrm{T} 6$ condition). Crack paths are artificially enhanced for clarity.

particles along the crack path are broken, Fig. 6(e), $f_{\mathrm{b}}$ attaining a value near $75 \%$ (Fig. 5(f)).

For the finer, $5 \mu \mathrm{m}$ polygonal alumina composites, matrix voiding remains the main fracture micromechanism whatever the $\mathrm{Cu}$ concentration and the heat-treatment. An example is the $\mathrm{Al}-4.5 \% \mathrm{CuT} 4 / 5$ $\mu \mathrm{mAl}{ }_{2} \mathrm{O}_{3} \mathrm{P} / 58_{\mathrm{p}}$ composite, Fig. 6(f).

\subsubsection{SEM fractography}

In as-cast composites a large amount of $\mathrm{Al}_{2} \mathrm{Cu}$ intermetallic is always found on the fracture surface. This is illustrated in Fig. 7(a) for $\mathrm{Al}-4.5 \% \mathrm{CuF} / 35 \mu \mathrm{mAl}_{2} \mathrm{O}_{3} \mathrm{~A} /$ 50 p: with $4.5 \% \mathrm{Cu}$ the $\mathrm{Al}_{2} \mathrm{Cu}$ is coarser than with $2 \%$ $\mathrm{Cu}$ [34]. After solution heat-treatment these coarse intermetallics are no longer found on the fracture surface, Fig. 7(b), although smaller residual secondary-phases are occasionally noticed. Fig. 7(c) shows the fracture surface of $\mathrm{Al}-4.5 \% \mathrm{CuF} / 25 \mu \mathrm{mAl} \mathrm{O}_{3} \mathrm{P} / 60_{\mathrm{p}}$. Large intermetallic phases, also visible in Fig. 1(b), promote extensive cavitation between the ceramic particles. After heat-treatment, Fig. 7(d) showing Al-4.5\%CuT4/25 $\mu \mathrm{mAl}_{2} \mathrm{O}_{3} \mathrm{P} / 60_{\mathrm{p}}$, these have disappeared from the fracture surface. Note also for this material the confirmation of extensive particle cracking, which is not observed for pure $\mathrm{Al}$ reinforced with the same particles [15], nor for $\mathrm{Al}-2 \% \mathrm{Cu}$ reinforced with smaller $15 \mu \mathrm{m}$ particles [34].

\section{Discussion}

\subsection{Composite mechanical properties}

Two contrasts emerge from the present data: (i) between composites reinforced with angular and polygonal particles on one hand and (ii) between composites with an as-cast and a heat-treated matrix on the other.

The importance of the particle nature is obvious from the data: as was found with a pure aluminium matrix [15], composites reinforced with polygonal alumina particles are far stronger (Fig. 2) and tougher (Fig. 5) than those reinforced with more commonly used angular crushed angular alumina. This is certainly linked with internal defects of the crushed angular alumina particles. Cracks are indeed visible in the scanning electron microscope along their surface, Fig. 8(a), whereas such defects were not found with polygonal alumina particles, Fig. 8(b). This difference in defect population can be attributed to the fact that particle comminution was used in 

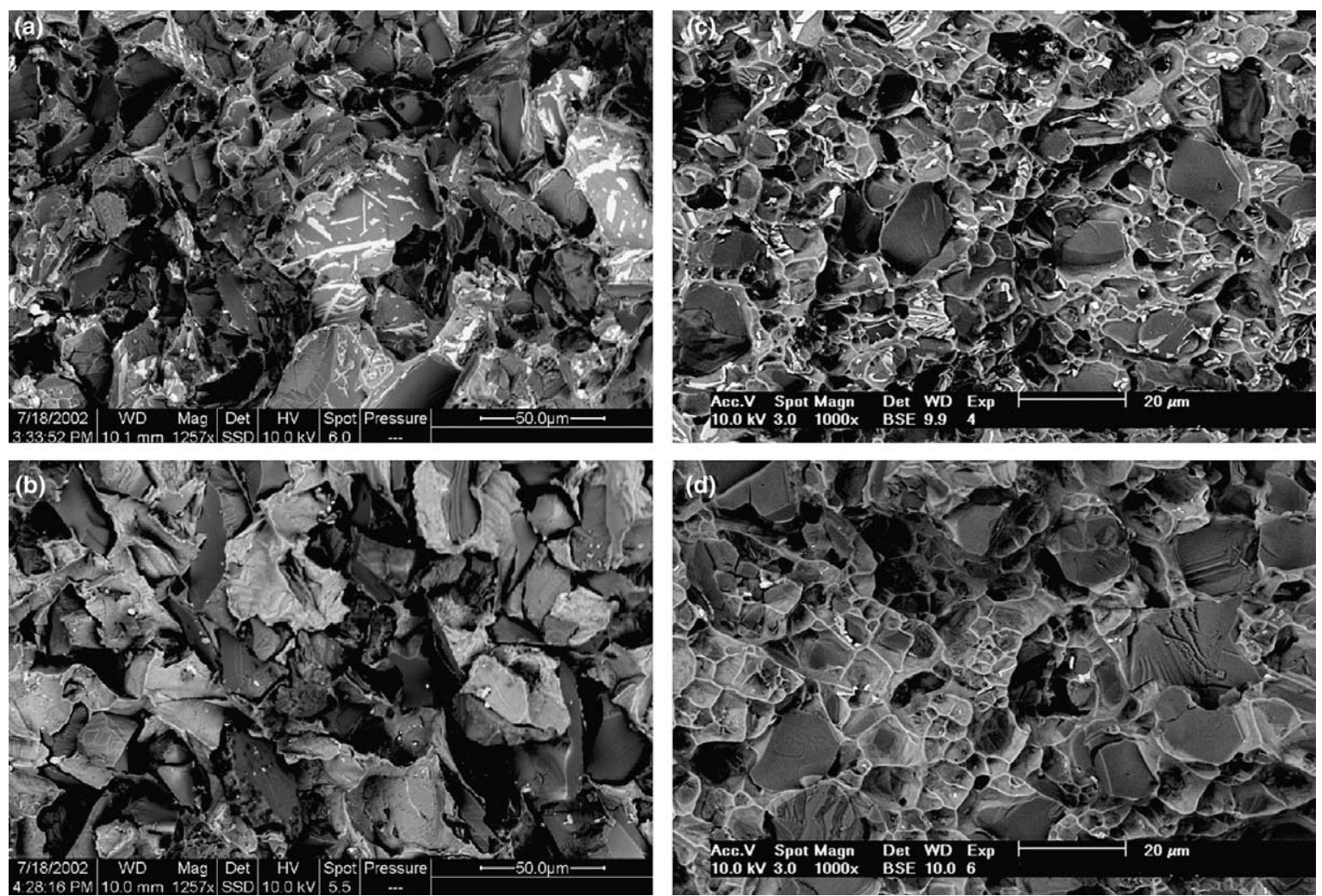

Fig. 7. SEM fractography of broken chevron-notched specimens. (a) $\mathrm{Al}-4.5 \% \mathrm{CuF} / 35 \mu \mathrm{mAl}_{2} \mathrm{O}_{3} \mathrm{~A} / 50_{\mathrm{p}}$; (b) $\mathrm{Al}-4.5 \% \mathrm{CuT} 4 / 35 \mu \mathrm{mAl}{ }_{2} \mathrm{O}_{3} \mathrm{~A} / 50_{\mathrm{p}} ;$ (c) $\mathrm{Al}-$ $4.5 \% \mathrm{CuF} / 25 \mu \mathrm{mAl}_{2} \mathrm{O}_{3} \mathrm{P} / 60_{\mathrm{p}}$; (d) $\mathrm{Al}-4.5 \% \mathrm{CuT} / 25 \mu \mathrm{mAl}_{2} \mathrm{O}_{3} \mathrm{P} / 60_{\mathrm{p}}$. Whereas secondary phases are seen at the bottom of small dimples in as-cast (F) composites, they are essentially absent after solution treatment ( $\mathrm{T} 4$ condition).

(a)

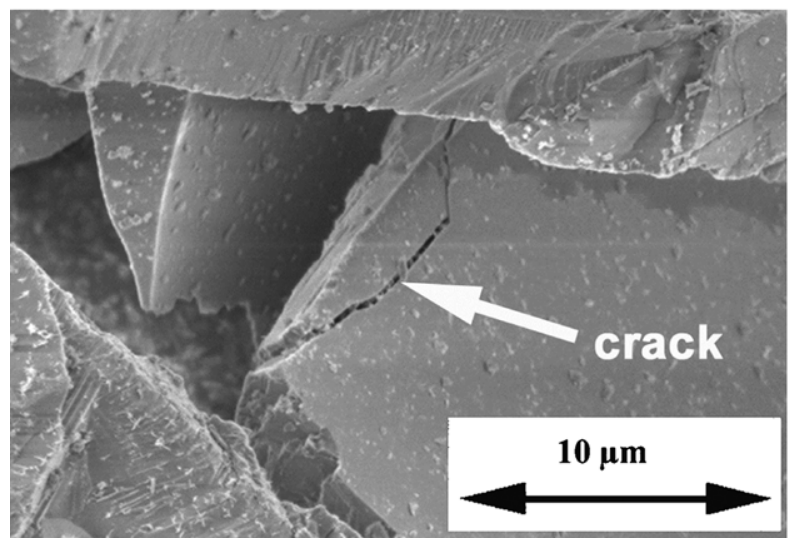

(b)

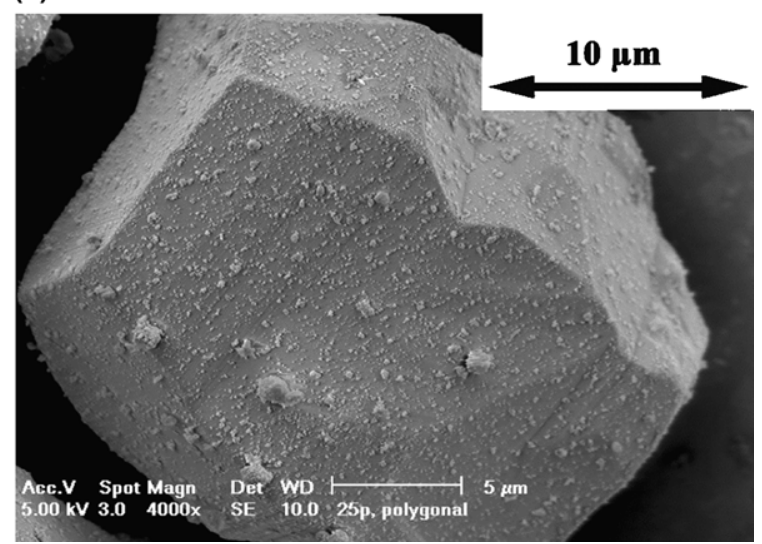

Fig. 8. SEM micrographs of typical ceramic powders: (a) angular $35 \mu \mathrm{m}$ particle, illustrating the presence of surface cracks; (b) polygonal $25 \mu \mathrm{m}$ particle.

the production of the angular alumina. A second difference between the two particle types is the more regular shape of the polygonal particles, a factor well known to reduce stress singularities in particle reinforced metals [46-50].

When the matrix is in the as-cast condition, the composite toughness decreases as the matrix flow stress increases, Fig. 5(a), as is often observed in aluminium alloys. After solutionization, on the other hand, when the matrix flow stress increases by alloying so does the composite toughness, Figs. 2 and 5(c). Aging the matrix changes only little composite properties, in both tension and fracture, Figs. 2 and 5. The simultaneous increase in composite strength and toughness that is found after solutionization is thus preserved after aging.

Such a simultaneous increase in composite strength and toughness with increasing matrix flow stress is a shift in composite properties towards globally improved 
mechanical performance. This is illustrated in Fig. 9(a) for selected reinforcements, combining results of [15] for a pure Al matrix with the present results for Al-2 and $-4.5 \mathrm{wt} \% \mathrm{Cu}$ in the $\mathrm{T} 6$ condition. In this condition, for the four particle types displayed on this graph (two angular and two polygonal), alloying the matrix globally improves the composite strength/toughness combination. The higher performance obtained with polygonal particles is also clearly evident on this graph.

Strength/toughness values for current high-strength aerospace aluminium alloys are also plotted in Fig. 9(a) [16]. As seen, these properties are matched by the Al-4.5wt\%CuT6 matrix composites reinforced with $\approx 60 \% 15$ or $25 \mu \mathrm{m}$ polygonal alumina particles. The tensile ductility of the composites is inferior (around 1\% vs. values around $10 \%$ for the alloys) but it remains acceptable for structural applications. The composites' Young's modulus, near $180 \mathrm{GPa}$, is 2.5 times that of aluminium alloys while their density is only around $20 \%$ higher: the structural performance of these isotropic composites in deflection-limited lightweight applications
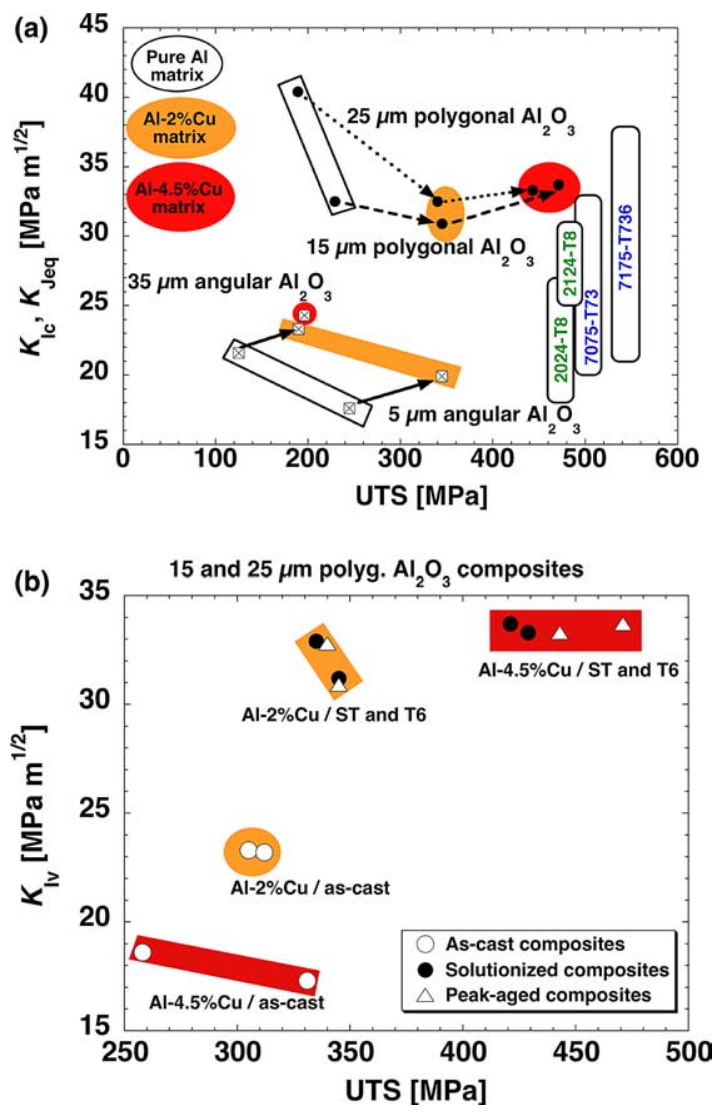

Fig. 9. (a) Strength-toughness combinations of the composites (alloyed matrices are in the T6 condition) together with corresponding property ranges for common aerospace $\mathrm{Al}$ alloys (2024, 2124, 7073, and 7175 alloys) [16]; (b) influence of matrix condition on the strength/ toughness combination of composites reinforced with 15 and $25 \mu \mathrm{m}$ polygonal particles: as-cast composites feature inferior properties due the presence of coarse $\mathrm{Al}-\mathrm{Cu}$ based intermetallics at interfaces. is thus around twice that of current engineering metals and alloys. Extensive mechanical characterization is necessary before these materials can be deemed fit for engineering usage; however, their potential in structural applications is obvious.

\subsection{Toughening mechanisms}

Toughening mechanisms of these composites are examined in [51]. In brief, the high composite toughness derives from a combination of four factors:

(i) The elastic modulus. Adding $60 \%$ alumina to aluminium causes an increase by a factor 2.5 in Young's modulus $E$ compared with unreinforced aluminium. The fracture energy $R$ may therefore be halved without lowering the fracture toughness $K$ of the composite, since $K \propto \sqrt{R E}$.

(ii) The formation and propagation of a macroscopic plastic zone surrounding the crack-tip. This is made possible by the fact that these composites are elastic-plastic, and hence capable of macroscopic plastic deformation around a propagating crack tip. The presence of extensive crack tip plasticity is deduced from the values taken by the ratio of toughness to yield stress of the composites. This is also demonstrated experimentally in a separate study, by revealing the crack-tip strain fields using reflective photoelasticity [42]. This feature creates a fundamental difference between the present composites and metal toughened ceramics (continuous ceramic, discontinuous metal) or interpenetrating phase composites (co-continuous metal and ceramic), both of which cannot exhibit macroscopic plasticity around a crack tip with a strong ceramic phase.

(iii) A peak bridging stress in the crack tip microfracture process zone that is sufficiently high to trigger amplification via crack tip plasticity of the local fracture energy, i.e., to trigger the "valve effect" of elastic-plastic fracture. As argued in [51], this must be achieved in the composites by means of the high stress triaxiality characteristic of the early stages of matrix void growth between the narrowly spaced ceramic particles.

(iv) The comparatively high local fracture energy $\left(\Gamma_{0}=2 \gamma_{\mathrm{pz}}\right)$ consumed in the formation of a dimpled ductile fracture surface, involving matrix cavity nucleation and growth.

Cohesive zone modeling (CZM) of elastic-plastic fracture [52-55] shows that these factors combined result in a high steady-state fracture energy, $\Gamma_{\mathrm{ss}}$ just as in ductile unreinforced metals. Specifically, $\Gamma_{\mathrm{ss}}$ is predicted to equal the local work of fracture $\Gamma_{0}=2 \gamma_{\mathrm{pz}}$ amplified by a factor $F$ that is principally a function of two parameters, namely (i) the work hardening exponent $n$ of the material and (ii) the ratio of the peak-stress $\sigma_{\mathrm{p}}$ of the local cohesive law (i.e., the maximum local 
crack bridging stress that is reached during crack face separation), to the yield stress $\sigma_{y}$ of the material

$\Gamma_{\mathrm{ss}}=\Gamma_{0} \cdot F\left(\frac{\sigma_{\mathrm{p}}}{\sigma_{y}}, n\right)$.

For $F$ to significantly exceed unity $\sigma_{\mathrm{p}} / \sigma_{y}$ must exceed a value that increases with $n$ and is around three if $n=0.1$, four if $n=0.2$. In the composites, satisfaction of this condition is explained by the fact that voids grow between two narrowly spaced and stiff ceramic particles: the early stages of void growth then occur under conditions of very high stress triaxiality. This raises the cohesive law peak stress $\sigma_{\mathrm{p}}$ to values near 6-8 times the matrix yield stress $\sigma_{y, \mathrm{~m}}$, i.e, 3-4 times the composite yield stress $\sigma_{y}$, satisfying the condition for $F$ to be appreciably above unity.

\subsection{The role of matrix flow stress and microstructure}

The contrast between composites with an as-cast matrix and those with a heat-treated (T4 or T6) matrix is then easily explained. As seen, as-cast composites are significantly less tough; this is summarized in Fig. 9(b) for composites with 15 and $25 \mu \mathrm{m}$ polygonal particles. Indeed, if the matrix contains weak intermetallics, these will crack at low stress, triggering void growth in the matrix. As-cast composites do indeed display large islands of brittle $\mathrm{Al}_{2} \mathrm{Cu}$ intermetallic located at the bottom of fracture surface microvoids, Fig. 7. The early stages of void nucleation and growth, during which high triaxiality causes an elevation of $\sigma_{\mathrm{p}}$, are then bypassed. The ratio $\sigma_{\mathrm{p}} / \sigma_{y}$ is then lowered, lowering in turn $F$ and the composite toughness $\Gamma_{\mathrm{ss}}$.

The absence of brittle intermetallics in the composites is, thus, an important factor for optimization of their mechanical performance. This conclusion parallels what has been found for lower volume fraction particle reinforced metals: brittle intermetallics, formed for example after overaging, are known to degrade the toughness of structural powder-metallurgy or stir-cast ceramic particle reinforced metals containing up to $30 \mathrm{vol} \%$ ceramic [6,21-24,26,27,56,57].

Once weak intermetallics are dissolved, voids nucleate within the matrix between particles under high stress triaxiality, regardless of matrix alloying. Hardening the matrix need then not prevent the cohesive law stress $\sigma_{\mathrm{p}}$ from peaking at three to four times the composite yield stress $\sigma_{y}$ : conditions for $F$ to be appreciably above unity can therefore still be met. The influence of the matrix flow stress on composite toughness is then largely exerted via the influence it has on the local work of fracture $\Gamma_{0}=2 \gamma_{\mathrm{pz}}$, a quantity that need not necessarily decrease as a consequence of matrix hardening. Indeed, $\Gamma_{0}$ essentially corresponds to the work spent tearing apart ductile metal ligaments: while matrix hardening will generally hasten instability in ductile dimple tearing, it will also increase the stress required for a given level of dimple deformation.

The average dimple height $h_{0}$ was estimated using quantitative fractographic measurements on $15 \mu \mathrm{m}$ polygonal particle reinforced composites. No significant difference was found between $\mathrm{T} 4$ and $\mathrm{T} 6$ composites, nor between $\mathrm{Al}-2 \% \mathrm{Cu}$ and $\mathrm{Al}-4.5 \% \mathrm{Cu}$ matrices: the measured dimple height remained at $2.4 \mu \mathrm{m}$ on average. This is about half the value of these composites' pure $\mathrm{Al}$ matrix counterpart [15]. The difference reflects differences between the pure metal and its alloys in the plastic flow path upon dimple formation, caused for example by differences in slip concentration or in the point of cavitation instability [58].

The data show that the composite toughness remains roughly constant as the matrix is alloyed, Fig. 9(a). The reduced dimple size and the greater proportion of cracked particles that accompany matrix alloying, Figs. 5 and 6 (both of which tend to decrease $\Gamma_{0}$ and hence lower the composite toughness), are thus seemingly counterbalanced by the higher matrix flow stress (which increases $\Gamma_{0}$ all else being equal). Comparison with data for lower volume fraction ceramic reinforced composites, reviewed by Lewandowski in [6], is not straightforward because industrial alloys are generally used in production of such composites. A few parallels can nonetheless be found, for example in the comparison of composites with $15 \mathrm{vol} \% \mathrm{Al}_{2} \mathrm{O}_{3}$ particles by Klimowicz and Vecchio (also given in Figs. 13 and 14 of [6]): their data also show a global increase in the composite toughness and strength combination as the matrix goes from lower-strength 6061 to higher-strength 2014 [59].

The limit to improvements in global composite performance that can be achieved by matrix alloying are largely set by the particles: as the matrix flow stress increases so does the stress experienced by the particles near the crack tip. Above a certain level, which depends on intrinsic particle properties, the ceramic phase will begin to crack extensively, lowering the local work of fracture $\Gamma_{0}$ significantly. This question is discussed in more detail in [51]; we show in particular that some level of particle fracture is compatible with the achievement of high composite toughness. This is evident in several of the composites of this work; see Fig. 5 (where one can for example notice that increases in the fraction of broken particles that accompany changes in the particle size or the matrix heat-treatment can be accompanied by an increase in composite toughness).

\subsection{Locallglobal toughness correlation}

It was shown in [15] that, with a pure Al matrix, this class of composites gives evidence of a straigthforward linear correlation between the local and the global 
fracture energies over a wide range of microstructures. In other words, with a pure Al matrix the "valve effect" amplifies by a roughly constant amplification factor $(F$ in Eq. (1)) the estimated local fracture energy $\Gamma_{0}$. In the present composites this neat correlation seemingly does not hold, at least not with the same clarity. This can be inferred by comparison of two selected composites.

In the $\mathrm{T} 6$ condition, $\mathrm{Al}-4.5 \mathrm{wt} \% \mathrm{Cu}$ composites reinforced with $25 \mu \mathrm{m}$ polygonal and $35 \mu \mathrm{m}$ angular alumina particles both feature around $75 \%$ cracked particles along the crack path, Fig. 5(f). Since the matrix is the same and the particle size is roughly the same, the dimple formation energy should be similar between the two composites. The fraction broken particles along the crack faces being also about the same, the local fracture energy, $\Gamma_{0}$, must in turn be very similar between the two. Yet, the fracture toughness of the polygonal particle reinforced composite is nearly $50 \%$ higher, Fig. 5(e) (33 vs. $24 \mathrm{MPa} \sqrt{ } \mathrm{m}$ ).

This observation can be rationalized using the simple model given in [51]: depending on the particle strength distribution, $\sigma_{\mathrm{p}} / \sigma_{y}$ may differ significantly between the two composites, causing in turn significant differences in the "amplification factor" $F$ of Eq. (1). Far more work would be needed to document with exactitude such variations in the "amplification factor" $F$; however, there seems to be no fundamental reason why this factor should remain constant as the composite microstructure changes.

In fact, it is the neat constancy of $F$ that was found with the pure matrix composites that is a priori surprising. The strain exponent $n$ being constant for those composites [60] the implication is that the ratio $\sigma_{\mathrm{p}} / \sigma_{y}$ is also approximately constant for the pure matrix composites - whereas it is seemingly not with alloyed matrices. Two factors could cause this: (i) the far smaller extent and hence smaller influence of particle cracking with the (weaker) pure Al matrix, and (ii) the greater microstructural simplicity of the pure Al matrix compared with $\mathrm{Al}-\mathrm{Cu}$ alloys, causing greater constancy in matrix void nucleation and growth mechanisms across the composites.

Still, despite the lack of a constant proportional relation between the local and the global fracture energies in these composites, trends with changing particle characteristics are globally as expected from their influence on the local fracture energy, $\Gamma_{0}$ :

- increasing the intrinsic particle strength, leading to a reduced fraction of broken particles along the crack path, increases the composite toughness, Figs. 5 and 9 ;

- increasing the particle diameter at first increases the composite toughness until the influence of particle fracture becomes dominant, Fig. 5.
A similar trend of increasing toughness with increasing particle size (generally accompanied by decreasing tensile strength) has also been observed in lower volume fraction composites, for example in MB78 and X2080 aluminium alloys reinforced with $\mathrm{SiC}$ particles; see the extensive review in [6].

\section{Conclusions}

Pressure-infiltrated composites consisting of around $50 \%$ polygonal or angular $\mathrm{Al}_{2} \mathrm{O}_{3}$ particles embedded within binary $\mathrm{Al}-\mathrm{Cu}$ alloys display the following fracture characteristics:

- Polygonal alumina reinforcements produce composites that are systematically stronger and tougher than angular alumina reinforced composites.

- Removing brittle $\mathrm{Al}_{2} \mathrm{Cu}$ intermetallics by solution heat-treatment leads to strong increases in composite strength and toughness.

- After matrix solutionization, matrix alloying improves the strength of these highly reinforced composites while preserving their high toughness.

- Current cohesive law models for the ductile fracture of elastic-plastic materials provide a coherent interpretation framework for the high toughness observed in the present composites, and for the influence of matrix flow stress on their toughness.

- With high-strength polygonal alumina particles, the strength/toughness combination of these highstiffness, half-metal/half-ceramic composites rivals that of current high-strength engineering $\mathrm{Al}$ alloys.

\section{Acknowledgements}

This work was funded by the Swiss National Science Foundation under Contract No. 2000-063575-00, with added support from core funding of the Swiss Federal Institute of Technology, Lausanne. The authors also thank Mr. Randoald Müller for providing some additional tensile data, and both Dr. Andreas Rossoll and Mr. Randoald Müller for many insightful discussions.

\section{References}

[1] Clyne TW, Withers PJ. An introduction to metal matrix composites. Cambridge: Cambridge University Press; 1993. p. 509.

[2] Hunt WH. In: Clyne TW, editor. Comprehensive composite materials. Metal matrix composites, vol. 3. Amsterdam: Elsevier; 2000. p. 701-15.

[3] Clyne TW. In: Clyne TW, editor. Comprehensive composite materials. Metal matrix composites, vol. 3. Amsterdam: Elsevier; 2000. p. 1-26.

[4] Gheorge I, Rack HJ. In: Clyne TW, editor. Comprehensive composite materials. Metal matrix composites, vol. 3. Oxford: Pergamon; 2000. p. 679-700. 
[5] Evans A, SanMarchi C, Mortensen A. Metal matrix composites in industry: an introduction and a survey. Dodrecht: Kluwer Academic Publishers; 2003. p. 423.

[6] Lewandowski JJ. In: Clyne TW, editor. Comprehensive composite materials. Metal matrix composites, vol. 3. Amsterdam: Elsevier; 2000. p. 151-87.

[7] Pestes RH, Kamat SV, Hirth JP. Mater Sci Eng A 1994;189:9-14.

[8] Seleznev ML, Argon AS, Seleznev IL, Cornie JA, Mason RP. SAE Technical Paper Series, 1998.

[9] Aghajanian MK, Langensiepen RA, Rocazella MA, Leighton JT, Andersson CA. J Mater Sci 1993;28:6683-90.

[10] Flom Y, Arsenault RJ. Acta Metall 1989;37:2413-23.

[11] Zhao D, Tuler FR. Eng Fract Mech 1994;47:303-8.

[12] Kamat SV, Hirth JP, Mehrabian R. Acta Metall 1989;9:2395-402.

[13] Burke JT, Aghajanian MK, Rocazella MA. In: 34th International SAMPE Symposium and Exhibition, Proceedings Conference, Reno, Nevada, 1989; Covina, California: SAMPE. p. 2440-54.

[14] Lu YX, Lee CS, Meng XM, Li RKY, Bi J. Phys Stat Sol $1998 ; 169$.

[15] Miserez A, Rossoll A, Mortensen A. Acta Mater 2004;52:1337-51.

[16] Polmear IJ. Light alloys - metallurgy of light alloys. 3rd ed.. London: Arnold; 1995.

[17] Davidson DL. Composites 1993;24:248-55.

[18] Lloyd DJ. Int Mater Rev 1994;39:1-23.

[19] Sinclair I, Gregson PJ. Mater Sci Technol 1997;13:709-25.

[20] Lloyd DJ, Jin I. In: Clyne TW, editor. Comprehensive composite materials. Metal matrix composites, vol. 3. Amsterdam: Elsevier; 2000. p. 555-77.

[21] Park JK, Lucas JP. In: Rohatgi PK, editor. Processing, properties and applications of cast metal matrix composites. Proc Conf, Cincinnati, OH. The Minerals, Metals \& Materials Society; 1996.

[22] Lucas JP, Park JK. In: Scoot ML, editior. 11th International Conference on Composite Materials. Proceedings Conference, Gold Cost, Queensland, Australia, 1997; Australian Composite Structures Society.

[23] Lewandowski JJ, Liu C, Hunt WH. Mater Sci Eng A 1989;107:241-55.

[24] Hunt WH, Osman TM, Lewandowski JJ. JOM 1993;45:30-5.

[25] Manoharan M, Lewandowski JJ. Scripta Metall Mater 1990;24:2357-62.

[26] Manoharan M, Lewandowski JJ. Mater Sci Eng 1992;150:179-86.

[27] Manoharan M, Lewandowski JJ. Int J Fract 1989;40:31-4.

[28] Murray JL. Int Metals Rev 1985;30:211-33.

[29] Mortensen A. In: Clyne TW, editor. Comprehensive composite materials. Metal matrix composites, vol. 3. Amsterdam: Elsevier; 2000. p. 521-54.

[30] SanMarchi C, Kouzeli M, Miserez A, Moser B, Rossoll A, Weber L, et al. In: Song J, Yin R, editors. ICETS 2000-Session 3: advanced materials conference. Proc Conf, Beijing, China. New World Press; 2000. p. 74-82.

[31] Kouzeli M, SanMarchi C, Mortensen A. Mater Sci Eng A 2002;337:264-73.

[32] Kouzeli M, Weber L, SanMarchi C, Mortensen A. Acta Mater 2001;49:3699-709.

[33] Miserez A. Fracture and toughening of high volume fraction ceramic particle reinforced metals, Thesis No. 2703 (available online at: http://library.epfl.ch/theses/?display=detail\&nr=2703) $\mathrm{PhD}$ thesis, 2002, Ecole Polytechnique Fédérale de Lausanne - EPFL.
[34] Miserez A, Stücklin S, Rossoll A, SanMarchi C, Mortensen A. Mater Sci Technol 2002;18:1461-70. and Erratum vol. 19, April 2003, p. 549-50.

[35] Kouzeli M, Weber L, SanMarchi C, Mortensen A. Acta Mater 2001;49:497-505.

[36] ASTM, E 1304-89: Standard test method for plane-strain (chevron-notch) fracture toughness of metallic materials, American Society for Testing and Materials, Philadelphia, 1989. p. 863-73.

[37] Mex, 3D-analysis of stereoscopic SEM-images, Alicona GmbH, Grambach, Austria (Reference manual available from: http:// www.alicona.com).

[38] Lebydokin M, Brechet Y, Estrin Y, Kubin L. Acta Mater 1996;44:4531-41.

[39] Pink E, Bruckbauer P, Weinhandl H. Scripta Mater 1998;38:945-51.

[40] Cheng X-M, Morris JG. Scripta Mater 2000;43:651-8.

[41] Grant TJ, Weber L, Mortensen A. Eng Fract Mech 2000;67:263-76.

[42] Miserez A, Rossoll A, Mortensen A. Eng Fract Mech 2004;71:2385-406.

[43] Tschanz TC, Matlock DK, Krauss G. In: Brown KR, Brown FI, Baratta FI, editors. Chevron-notch fracture test experience: metals and non-metals. Proc Conf, Indianapolis, IN. Philadelphia (PA): ASTM; 1991. p. 26-42.

[44] Brown KR. In: Underwood JH, Freiman SW, Baratta FI, editors. ASTM-STP 855: chevron-notched specimens, testing and stress analysis. Proc Conf, Philadelphia. Philadelphia (PA): ASTM; 1983. p. $237-54$.

[45] Morrison J, Karis Allen KJ. In: Brown KR, Freiman SW, Baratta FI, editors. ASTM-STP 1172: chevron-notch fracture test experience metals and non-metals. Proc Conf, Indianapolis. Philadephia (PA): ASTM; 1992. p. 43-53.

[46] Qin S, Chen C, Zhang G, Wang W, Wang Z. Mater Sci Eng A 1999;272:363-70.

[47] Song SG, Shi N, Gray GT, Roberts JA. Metall Mater Trans A 1996;27:3739-46.

[48] Watt DF, Xu XQ, Lloyd DJ. Acta Mater 1996;44:789-99.

[49] Llorca J, Gonzalez C. J Mech Phys Solids 1998;46:1-28.

[50] Chen CR, Qin SY, Li SX, Wen JL. Mater Sci Eng A 2000;278:96-105.

[51] Miserez A, Müller R, Rossoll A, Weber L, Mortensen A. Special issue of the 13th International Conference on the Strength of Materials (ICSMA 13), Budapest, 2003, Mater Sci Eng A 2004, in press.

[52] Tvergaard V, Hutchinson JW. J Mech Phys Solids 1992;40:1377-97.

[53] Tvergaard V, Hutchinson JW. Int J Solids Struct 1996;33:3297-308.

[54] Hutchinson JW. In: Willis JR, editor. IUTAM symphosium on nonlinear analysis of fracture. Proc Conf. Dordrecht: Kluwer Academic Publishers; 1997. p. 81-91.

[55] Li H, Chandra N. Int J Plasticity 2003;19:849-82.

[56] Shakeri HR, Wang ZR. Metall Mater Trans A 2002;33:1699-713.

[57] Manoharan M, Lewandowski JJ. Acta Metall Mater 1990;38:489-96.

[58] Huang Y, Hutchinson JW, Tvergaard V. J Mech Phys Solids 1991;59:223-41.

[59] Klimowicz TF, Vecchio KS. In: Liaw PK, Gungor MN, editors. Fundamental relationships between microstructure and mechanical properties in metal matrix composites. Warrendale (PA): TMS; 1990. p. 255-300.

[60] Kouzeli M, Mortensen A. Acta Mater 2002;50:39-51. 